\title{
Radicales y socialistas en la Argentina peronista: (1946-1955) $)^{1}$
}

\author{
Marcela García Sebastiani \\ Universidad Complutense de Madrid
}

\section{Introducción}

Desde la victoria electoral de Perón en 1946, el resentimiento entre sus partidarios y sus contrarios ha sido una de las características más recurrentes en la historia política argentina contemporánea. La necesidad de explicar la novedad de un fenómeno que parecía haber alterado las normas hasta entonces típicas de hacer política en el país, justificó numerosos análisis políticos y no pocos combates intelectuales que procuraron desvelar tanto los aspectos fundacionales del peronismo, como los signos de identidad que permitieron su posterior consolidación en el poder. ${ }^{2}$ En las últimas décadas el debate sobre el peronismo se enriqueció en temas y matices, dando paso a un progresivo y animado diálogo historiográfico. ${ }^{3}$ Sin embargo, los casi diez años que gobernó Perón no se definen sólo por los cambios introducidos en las formas de ejercitar la política y en el establecimiento de nuevos códigos en la relación del Estado con determinados sectores de la sociedad, sino también por las acciones, ideas y conflictos de quiénes se le opusieron. El peronismo generó una oposición política y redefinió al adversario para los partidos que tradicionalmente competían en la escena política argentina. El proceso derivó en la conformación de un paradigma antagónico con un profundo impacto en la definición de la cultura política de los argentinos. Además de Perón y su entor-

1 Para una primera versión en inglés de este trabajo, García Sebastiani (2003: 311-339).

2 Para una bibliografía sobre el peronismo, Hortvath (ed.) (1993). Para las diferentes interpretaciones del peronismo desde su derrocamiento en septiembre de 1955 hasta finales de la década del 80, Plotkin (1991: 112-135). Más recientemente, Macor y Tcach (2003).

3 En los trabajos más destacados de la última década ver, a manera de ejemplo, Torre (1990), Horowitz (1990), James (1990), Tcach (1991), Plotkin (1993), Caimari (1995), Bianchi (2001), Neiburg (1998), Rein (1998), Zanatta (1999), Torre (dir.) (2002), Macor / Tcach (eds.) (2003). 
no de poder, existían otros actores que dieron sentido a la vida política de la Argentina entre 1946 y 1955. De lo contrario, ¿tiene algún sentido hablar de la disyuntiva políticamente irreconciliable entre el peronismo y el antiperonismo de aquellos y futuros tiempos sin saber cómo y por qué se conformó este último y cuáles fueron las conductas y estrategias políticas que lo identificaron como tal? ${ }^{4}$

Desde una dimensión específica de la historia política, qué pasó con los radicales y socialistas durante la etapa peronista y cómo manifestaron su oposición al gobierno es el tema de este capítulo. Tal compromiso supone superar el riesgo de dar por válidas aquellas feroces y reprobables acusaciones de los antiperonistas que proliferaron en diversas publicaciones en los años inmediatamente posteriores al movimiento cívico-militar que destituyó a Perón en 1955. Tales opiniones deslegitimadoras de cualquier acción gubernamental y de los líderes políticos de la década peronista sirvieron de punto de partida para muchas interpretaciones históricas por suerte hoy superadas, pero también definieron los argumentos de crítica que usualmente ha utilizado la opinión pública en el intento de explicar la polarización de la vida política argentina en función de la dinámica excluyente entre peronismo y antiperonismo. Generalizaciones en torno a las limitaciones de ciertos espacios de expresión de la disidencia como rasgo propio de un régimen que abrigaba aspiraciones de carácter totalitario, construidas sobre todo desde el campo intelectual a partir del derrocamiento de Perón, poco alentaban a formular preguntas acerca de la oposición política en el periodo. Los sucesivos gobiernos de Perón intentaron preservar, de una y otra manera, ciertas facetas legitimadoras de una pluralidad política. Se conservaron las instituciones republicanas del país: el Congreso y el Poder Judicial no dejaron de funcionar, se celebraron regularmente elecciones nacionales, provinciales y -aunque tardaron inicialmente en convo-

4 El escaso interés académico por el tema de la oposición política en el conjunto de los países latinoamericanos puede tener diferentes lecturas. El debate sobre el tema fue especialmente rico en los Estados Unidos y en Europa durante las décadas del 60 y del 70, cuando se consolidaron las democracias surgidas en la postguerra. Sin embargo, América Latina difícilmente podía hacerse eco del debate. Los regímenes autoritarios que por entonces se habían impuesto en casi todos los países de la región generaron preguntas sobre por qué surgieron y cuáles eran sus características más distintivas. La crisis de tales regímenes en los años 80 necesitó explicaciones sobre las posibilidades de transición a la democracia y, más tarde, sobre las condiciones de gobernabilidad. Con todo, algunos trabajos pioneros sobre el tema de la oposición política merecen destacarse para el caso de Argentina. Por ejemplo, Smulovitz (1988), Mustapic y Goretti (1992). También, García Sebastiani (2005). Sobre el escaso debate en torno al tema de la oposición política en la Argentina ver prólogo a la edición argentina de Franco Castiglioni a la compilación de Pasquino (1998: 7-34). 
carse- las municipales. El propio Perón fue electo presidente dos veces seguidas por medio de elecciones libres y en las que participaron los partidos de la oposición -aún con normativas de representación que les desfavorecían. Si bien en las elecciones nacionales el margen de diferencia de votos a favor de Perón se incrementó gradualmente desde las ajustadas elecciones de 1946, la oposición conservó a lo largo del periodo, como mínimo, un 30\% del electorado nacional, y en ese sentido representó una alternativa de poder. Por tanto, la vida política de la Argentina entre 1946 y 1955 no hay que leerla sólo en términos de la emergencia y consolidación del peronismo, ni simplificar los análisis sugiriendo que los gobiernos peronistas cercenaron los espacios a sus contrarios de la manera que lo hicieron los regímenes totalitarios con los que comúnmente se lo ha comparado. Gobierno y oposición gozaban, pues, de legitimidad para la competencia política. Sabido es que la naturaleza y el funcionamiento de un régimen político es explicable de modo eficaz en la medida en que se diluciden el tipo de relaciones entre gobierno y oposición. ${ }^{5}$ En el caso que nos ocupa, el abordaje del problema es especialmente difícil porque, a pesar de ser un periodo relativamente corto de la historia política argentina, el peronismo no fue el mismo a lo largo de toda la década. Diferentes han sido las relaciones del gobierno con la oposición entre 1946 y 1948, que entre 1949-1952 y, finalmente, entre 1952 y 1955. A lo largo de esos años no faltaron limitaciones a la opinión disidente, pero eso no quiere decir que hayan sido siempre de igual calibre, ni que tampoco el peronismo haya procurado mantener ciertas reglas del juego democrático en medio de un contexto internacional que el hundimiento del fascismo había alentado a respetarlas.

Con todo, cualquier acercamiento al estudio de la oposición política implica tener presentes algunas cuestiones. En primer lugar, es fundamental conocer cuáles son los espacios de enfrentamiento entre el gobierno y su oposición política. Ciertamente, la estructura institucional delimita los lugares de encuentro a partir de los cuales los diferentes actores políticos despliegan sus acciones y la oposición se define como alternativa al gobierno, aunque es sabido que el conflicto político no siempre se desarrolla dentro de los marcos institucionales (Dahl 1974; Ionescu y de Madariaga 1977). El espectro de oportunidades y las posibilidades de acción de la oposición serán diferentes según la manera en que estén asignados los recursos políticos en la división de poderes, de las normativas electorales que regulen las formas de representación y del funcionamiento del sistema de partidos. El diseño constitucional argentino,

5 Para la oposición en regímenes democráticos, ver, fundamentalmente, Dahl (ed.) (1966), (1973). Para regímenes no democráticos, Linz (1973: 171-259) y Pasquino (1974: 421-439). 
como es sabido y se ha insistido demasiado, el Poder Ejecutivo goza de mayores recursos institucionales disponibles respecto a los demás poderes y esto supone inevitables consecuencias en las relaciones con la oposición en la medida en que tiende a debilitar su capacidad de control y de definición de estrategias desde el Parlamento. En tales sistemas, el peso de este último es menor y el presidente tiene, según las constitucionales nacionales, atribuciones legislativas propias y exclusivas. No quiere decir esto que el Congreso no sea un espacio de confrontación y de negociación política, ni tampoco que imposibilite la articulación con otras sedes de acción opositora alternativas a los canales institucionales. ${ }^{6}$ Después de todo, es en ese ámbito donde actúan aquellos actores políticos que las consultas electorales dejaron al margen de la representación institucional (Ionescu y de Madariaga 1977: 96-116 y Kolinsky (ed.) 1987).

Por otra parte, difícil es abordar a la oposición política si no se analiza a los partidos políticos. La cuestión es especialmente compleja para el caso de la historia argentina por varias razones. Entre ellas, cabe señalar la escasamente garantizada estabilidad de un sistema de partidos debido a la discontinuidad de la alternancia democrática, el cuestionamiento de la legitimidad de la representación político-partidaria, y la importancia concedida a la acción política de ciertos líderes sobre las instituciones. En cualquier caso, entre los partidos políticos contrarios a Perón, la Unión Cívica Radical (UCR) concentró el mayor poder de representación institucional según los resultados electorales. Por el contrario, a partir del triunfo del peronismo en la escena política nacional, el Partido Socialista (PS) perdió el relativo margen de representación y de decisión en la vida pública del que gozaba desde principios de siglo. En la búsqueda de espacios para competir de algún modo en la arena política se constituyó en la oposición más enconada y crítica contra el peronismo, lo que no impidió, sin embargo, su inminente declinación como una de las principales fuerzas políticas del país. Por tanto, cualquier referencia sobre la oposición a los gobiernos de Perón supone adentrarse en la dinámica interna y en la dimensión de poder de esas organizaciones. Implica, en definitiva, desvelar tanto la estructura que gestiona y ejecuta las decisiones del partido como los pormenores y los conflictos derivados del control de la misma y que, inevitablemente, terminarán conformando alianzas o divisiones entre sus miembros.

6 El debate sobre las relaciones entre PE y PL ha sido, durante la década pasada, rico en matices. Al respecto, Linz (1977: 25-143), Shugart y Carey (1992), Mainwaring y Shugart (1994: 397-418), Mainwaring y Shugart (1997). Para el caso concreto de la relación en la historia argentina, Fenell (1971: 139-1719) y Molinelli (1991). Para los gobiernos democráticos de Raúl Alfonsín y el primero de Carlos Menem, Mustapic (2000: 85-108). 
Concebido el problema desde esa perspectiva, no será desacertado inferir que las prácticas y estrategias últimas de la oposición al peronismo van a estar determinadas por la capacidad de organización y por la decantación de las luchas de poder en el interior de los partidos políticos. De por sí, en tanto partidos en la oposición juegan con cierta desventaja en la competencia con el partido del gobierno. Por ejemplo, no pueden apoyarse en burocracia, ni utilizar el Estado y sus aparatos; tampoco gozan del apoyo financiero que los grupos de interés reservan al partido en el gobierno. ${ }^{7}$ Una última cuestión que tal vez haya que indagar, y que en estas páginas apenas se esboza, es el tipo de relaciones que los partidos en la oposición conformaron con otros actores que participaron en la coyuntura, como lo fueron las entidades corporativas o el universo intelectual antiperonista. La referencia es especialmente indicativa para entender cómo se manifestó la oposición durante el segundo periodo presidencial de Perón, sobre todo por la participación de las Fuerzas Armadas y de la Iglesia en su derrocamiento en septiembre de 1955 y por las posteriores lecturas del peronismo para la vida política argentina.

\section{La Unión Democrática: una tradición de unidad interpartidaria}

La Unión Democrática fue la alianza acordada por los diferentes partidos que tradicionalmente competían en la arena política para ofrecer una alternativa electoral a la continuidad de régimen militar que, habiéndose hecho con las riendas del poder en 1943, no parecía ofrecer, a los ojos de los contemporáneos del proceso, cambios innovadores en la política argentina a pesar de haber convocado elecciones para abril de 1946 y que terminaron adelantándose para el mes de febrero. Para los líderes con una larga trayectoria política y que trabajaron a favor de la unificación interpartidaria, Perón era el candidato del oficialismo que no tenía un partido político propio y del que no esperaban sorpresas en las urnas. En ese sentido no fue la opción de oponerse a Perón la que precipitó la coalición de las fuerzas políticas tradicionales ¿Debían acaso calibrar las posibilidades políticas de Perón o reconocer en él a un nuevo líder carismático que alteraría las formas de relación del Estado y los partidos con la sociedad antes de una confrontación electoral que decidiría la voluntad de los ciudadanos? ${ }^{8}$ Las explicaciones organizadas a posteriori del triunfo electo-

7 Sobre estas cuestiones, Panebianco (1990), especialmente el capítulo V.

8 En ese sentido, resulta sugerente la siguiente observación: “¿Qué rasgos nuevos llevaba ya inscritos, como consecuencia de esas transformaciones, la Argentina de 1943? Sin duda los contemporáneos de ella hubieran sido menos capaces de indicarlos que los 
ral de Perón, y sobre la novedad que significó el surgimiento de su movimiento para la vida política, llevan implícito el riesgo de pasar desapercibido el hecho de que la configuración de la alianza respondió a pautas de entendimiento interpartidario que estaban presentes entre las opciones políticas del espectro partidario argentino desde la década de 1930. De él, además, habían participado la mayoría de los dirigentes políticos que decidieron coaligarse en la Unión Democrática dos meses antes de las elecciones de febrero de 1946. Obedecían, eso sí, a la influencia de los acontecimientos europeos en el debate político argentino y se habían manifestado en coyunturas concretas.

Por ejemplo, para los comicios presidenciales del 8 de noviembre 1931, convocados por el general Uriburu en el intento de legitimar de algún modo la crisis institucional que provocó el golpe militar de 1930, la UCR había optado por la abstención, pero demócrata progresistas y socialistas habían decidido conformar una coalición electoral. La denominaron Alianza Civil y proclamaron las candidaturas de Lisandro de la Torre-Nicolás Repetto para los cargos presidenciales. ${ }^{9}$ En dichas elecciones triunfó la candidatura de Agustín P. Justo-Julio A. Roca, resultado, a su vez, de una coalición electoral en la que se habían comprometido varias agrupaciones políticas: el Partido Socialista Independiente, liderado por Antonio De Tomaso y escindido cuatro años antes del PS; los conservadores que se habían organizado en el Partido Demócrata Nacional; algunos sectores del radicalismo contrarios al liderazgo de Hipólito Yrigoyen en el partido, aunque también desencajados del proceso de reorganización partidaria que por entonces iniciaba Marcelo T. de Alvear; y, por último, un conjunto de asociaciones de carácter independiente (De Privitello 1994: 75-96; Fraga 1993: 215-242).

Hacia 1936, y a la luz de la experiencia de los Frentes Populares en el escenario europeo, se había formado una conjunción opositora al gobierno de la que formaron parte la UCR, el PS, el Partido Demócrata Progresista y el Partido Comunista. Las organizaciones de trabajadores y estudiantiles más representativas, como la Confederación General de Trabajadores y los estudiantes de la Federación Universitaria Argentina, se habían pronunciado a favor de la coalición. El entonces llamado Frente Popular despertó las más exacerbadas críticas por parte de los conservadores en el poder, pero a pesar de los agitados pronunciamientos de unos y cautelosos discursos de otros, la idea no se decan-

estudios actuales, a veces demasiado seguros de sus análisis retrospectivos; aún la novedad misma de esos rasgos era adivinada más que advertida", Halperin Donghi (1986: 18).

9 Al respecto, Dickmann (1949: cap. XI). También, Larra (1942: 107) y Siegler (1984: $50-55)$. 
tó en la formulación de una candidatura de alianza para las elecciones presidenciales de 1937. Los radicales habían decidido no integrarse a la coalición y acudir con candidatos propios. ${ }^{10} \mathrm{El}$ rechazo de la UCR afectaba directamente a los intereses políticos de los socialistas porque aquélla había decidido, después de cuatro años, levantar su abstención electoral en 1935 y, por tanto, pasaba a formar parte de la competencia por el electorado. Tras la derrota del radicalismo en los comicios de 1937 a favor de los candidatos conservadores, los socialistas procuraron, por todos los medios, controlar y beneficiarse de las posibilidades de entendimiento con la UCR para lograr algún tipo de acuerdo de cara a la celebración de elecciones para la renovación de diputados en marzo de 1938. A pesar de las propuestas del dirigente socialista Nicolás Repetto al líder de la oposición radical, Marcelo T. de Alvear, y de los propósitos ratificados en la máxima reunión del PS, el acuerdo no llegó a concretarse. ${ }^{11}$

La definición a favor o en contra de los contrincantes en el conflicto internacional desatado por la Segunda Guerra Mundial había escindido a la sociedad argentina en dos polos político-culturales. Quienes habían decidido pronunciarse en defensa de la causa de los Aliados emprendieron una declarada lucha antifascista desde ámbitos proclives a un pensamiento liberal y cosmopolita como la Universidad y, fuera de ella, diferentes instituciones culturales que acabaron tomando un carácter abiertamente político. ${ }^{12}$ Destacados y representativos miembros del espectro partidario en la oposición decidieron sumarse a ese clima de denuncias civiles contra los peligros de unas prácticas autoritarias y antidemocráticas que imputaban a los gobiernos conservadores. En junio de 1940 fundaron una organización civil, que denominaron Acción Argentina y desde ella, exhortaron "a todos lo partidos políticos a la unión y coordinación para tener una determinación solidaria ante las graves amenazas de la hora". ${ }^{13}$ Acción Argentina se constituyó como un elemento de socializa-

10 Sobre el tema, Rouquié (1981: 271-273); Ciria, (1986a: 68-70); Repetto (1957: 157 y ss.) y Cataruzza (1997: 56-57).

11 En la entrevista con el dirigente radical, Repetto comentó que “... consideraba más urgente que nunca la necesidad de organizar un gran movimiento de opinión destinado a dar con el modo más práctico y eficaz de llegar a restablecer en el país el imperio de la legalidad y crear la posibilidad de una convivencia fecunda y digna de los partidos...", El Partido Socialista y la Unión Democrática (s/f) y Anuario del Partido Socialista (1946: 25).

12 Sobre Acción Argentina, Fitte / Sánchez Zinny (1944: I, 254-255). Sobre la Universidad y otras instituciones culturales, Neiburg (1998: cap. 4), Halperin Donghi (1962) y Walter (1968).

13 Formaron parte de los órganos directivos de esa agrupación Nicolás Repetto, Mario Bravo y Américo Ghioldi por el PS, Julio A. Noble por el Partido Demócrata Progresista; M T. de Alvear, Emilio Ravignani, Eduardo Laurencena y Ernesto Boatti por la UCR; 
ción política que posibilitó el germen del entendimiento interpartidario sobre valores liberales y democráticos y que, más tarde, se decantaría en la formación de la Unión Democrática. A finales de 1941, las decisiones gubernamentales, que por entonces estaban a cargo del conservador Ramón Castillo, afectaron especialmente a los partidos de la oposición: se clausuró el Concejo Deliberante de la Ciudad de Buenos Aires, espacio dominado por radicales y socialistas opuestos al régimen, y se estableció el estado de sitio. Acción Argentina se convirtió entonces en la plataforma para el relanzamiento de la propuesta de coalición entre las distintas fuerzas políticas. ${ }^{14}$ Como había ocurrido en anteriores ocasiones, la iniciativa surgió del PS y contó con el respaldo de los sindicatos y estudiantes. Ni el Partido Demócrata Progresista ni la UCR formaron parte de esas primeras conversaciones a favor de "la coalición de unidad", por la que inicialmente apostaron el PS y Acción Argentina, difundiendo la idea a través de actos de propaganda, fundamentalmente, en la Capital Federal, Córdoba, Santa Fe y diferentes pueblos de la provincia de Buenos Aires. ${ }^{15}$ Para la UCR, la integración a la proyectada coalición terminó siendo la alternativa que la agrupación consideró más idónea en medio de una crisis de dirección por la que diferentes grupos pugnaban a raíz de la muerte de su líder, Marcelo T. de Alvear, en enero de 1942. Las dificultades por la que estaba atravesando la UCR se habían puesto de manifiesto en unos malos resultados en los comicios celebrados en la ciudad de Buenos Aires en marzo de 1942 para renovar parte de la Cámara de Diputados. La propuesta de integrarse a una comisión pro Unión Democrática Argentina, de la que ya formaban parte el PS y Acción Argentina, y más tarde el Partido Demócrata Progresista, se decidió, no sin diferencias internas, en la Convención Nacional de la UCR convocada para enero de 1943 (Luna 1986: I, 331). La coalición electoral se estaba definiendo de cara a unos anunciados comicios generales que se celebrarían en septiembre de 1943. Cuando el 4 de junio estalló el movimiento militar, del que Perón participó y del que emergería como posibilidad política, los partidos integrantes de la entonces Unión Democrática estaban en el punto máximo de discusión por el perfil partidario o extrapartidario de los candidatos presidenciales.

y Reynaldo Pastor, Vicente Solano Lima y Antonio Santamarina, conservadores que se negaban a respaldar a los gobiernos surgidos de la concordancia, Fitte y Sánchez Zinny (1944: 254-255 y 275).

14 "Frente a la situación interna ... lanzamos desde ya la idea, sin eludir obligaciones y responsabilidades, de un acercamiento de todas las fuerzas políticas, y no proyectamos exclusión alguna". El Partido Socialista y la Unión Democrática (s/f) y La Vanguardia, 29 de diciembre de 1941.

15 Fitte / Sánchez Zinny (1944: 397-406). 
Luego del levantamiento militar, muchos de los dirigentes políticos que habían participado en el debate en torno a la Unión Democrática se exiliaron en Montevideo por temor a ser perseguidos y, desde allí, prosiguieron los contactos para la concreción de algún tipo de acuerdo. ${ }^{16}$ Por eso, cuando desde mediados de 1945 las organizaciones extra partidarias, que propiciaron especialmente los sectores estudiantes y profesionales, se manifestaron contra el régimen y se pronunciaron por la restauración de las instituciones democráticas, ${ }^{17}$ los dirigentes de los partidos políticos y con una larga trayectoria pública pensaron que no tenían por qué redefinir una solución de entendimiento interpartidario por la que venían trabajando desde años antes. A la luz de la efervescencia que había desatado el final de la Guerra Mundial en el debate político argentino, los dirigentes del espectro partidario no vacilaron en recuperar una tradición de alianza entre los partidos para presentarse a las elecciones de febrero. Creyeron que la defensa de los valores democráticos era suficiente argumento y garantía para triunfar en los comicios.

\section{Peronistas y radicales en el Congreso Nacional}

La victoria de Perón en las elecciones de febrero de 1946 sobre los candidatos de la Unión Democrática no había sido exagerada en términos de votos, ${ }^{18}$ pero causó tal sorpresa y perplejidad entre los actores políticos que se habían definido por la unidad contra el régimen militar que, incluso, les condicionó a pensar sobre las causas de su derrota. Rota la coalición electoral una vez conocidos los resultados finales, cada uno de los partidos tuvo que elaborar, por separado, sus estrategias contrarias al gobierno que presidió Perón a partir de junio de 1946. La tarea no era fácil, ya que algunos ni siquiera habían obtenido representación en las instituciones del Estado, como el PS. Otros habían perdido dirigentes y militantes a favor de la causa peronista, como era el caso de los conservadores o los radicales, y también de los socialistas. ${ }^{19}$ Por eso, para los partidos que tradicionalmente disputaban los votos de los argentinos

16 Al respecto, Nudelman (1947).

17 Para la coyuntura de exaltación democrática previa a los comicios de febrero de 1946, Luna (1971).

18 Del total de los 2.839.507 votos emitidos (todos de varones), Perón obtuvo 1.487.886 (52,40\%) y la Unión Democrática 1.207 .080 (42,51\%), Cantón (1973: 272).

19 Sobre la formación del Partido Peronista y los conflictos dentro de la colación, Mackinnon (1995: 223-256). Sobre la alianza de Perón con los sectores conservadores, Llorente (1980: 269-317) y Esteves (1980: 318-364). También, Tcach (1991: 89-90). Sobre socialistas convertidos a la causa peronista, Rein (1998: 51-83). 
desde comienzos del siglo, cómo oponerse al peronismo terminó siendo una cuestión de supervivencia política, de la que la UCR parece haber salido más airosa.

Los resultados de las elecciones de 1946 señalaron a esa agrupación política como la principal fuerza de oposición y delimitaron los espacios institucionales de confrontación política. Conforme al diseño constitucional argentino, asentado en la división de poderes, el Congreso era uno de los ámbitos centrales para el control institucional al ejecutivo peronista. La oposición había logrado una representación de 49 diputados de un total de 158, pero de ningún senador. La Cámara de Diputados quedó confinada, por tanto, como uno de los centros de la competencia entre los dos partidos más representados y en el espacio de confrontación político-institucional entre gobierno y oposición. Allí, la oposición radical debió concentrar sus esfuerzos contra la política gubernamental en un espacio político que no sesionaba desde finales 1942 y que su reapertura generaba gran expectación política. Unos y otros sabían que lo que ocurriría en el recinto parlamentario marcaría uno de los pulsos más interesantes de la vida política en el ámbito nacional.

La oposición al peronismo en el Congreso provino, fundamentalmente, del Bloque de los 44 diputados radicales, estimado incluso por los diputados del bloque que conformaba el peronismo; ${ }^{20}$ otros cinco diputados opositores procedían de otras fuerzas políticas. Los radicales, sin embargo, no sólo debían definir las estrategias de oposición al gobierno que desarrollarían en el Congreso, sino también organizar su partido internamente. La derrota ante el peronismo había desencadenado tal crisis en la dirección nacional de la UCR que, si no encontraba soluciones rápidas, le sería difícil coordinar las prácticas políticas más atinadas como principal partido de oposición. La lucha en el interior del partido se tradujo en la resistencia de ciertos dirigentes que habían apoyado el compromiso de unidad interpartidaria como mejor solución para el radicalismo (y que por eso los distinguían como unionistas) a entender que

20 "(Los radicales) ya tenían unos hombres hechos: Santander, Sanmartino, Nerio Rojas, Absalón Rojas, Balbín, Frondizi, el coronel Pomar, era un bloque que ... nosotros que veníamos del radicalismo teníamos un gran respeto, una gran admiración por ellos, queríamos escucharlos y hasta esperábamos que los sentimientos radicales irigoyenistas comprendieran la posición nuestra y sobre todo la plataforma sobre la cual actuaríamos ... se llamaron los 44 de fierro, era una representación muy capaz, muy luchadora". Entrevista a Oscar Albrieu, Archivo de Historia Oral, Instituto Torcuato Di Tella. Colom, por su parte, comentaba sobre los diputados radicales: “... fue una oposición brillante por la calidad de sus componentes y eran opositores sistemáticos, eran superiores en calidad ...". Entrevista a Eduardo Colom, Archivo de Historia Oral, Instituto Torcuato Di Tella. 
había que introducir ciertas reformas en la organización tendentes a democratizar las principales decisiones de la agrupación política. Las divergencias internas del radicalismo entre diferentes tendencias eran intrínsecas a la historia misma de la organización partidaria y no faltaron durante los años que tuvo que oponerse al peronismo. ${ }^{21}$ Difícilmente podrían aquellas plantearse sólo como la disputa de dos bandos opuestos, uno más conservador, el de los unionistas, y otro de raíz popular, nacionalista, y reivindicativo de los principios del yrigoyenismo, que en esos tiempos acabarían definiéndose como intransigentes.

La conformación de las listas de candidaturas por la UCR para las elecciones del 46 había permitido la entrada en el Parlamento de varios dirigentes jóvenes y de ideas renovadoras que, desde años atrás, pugnaban por encontrar cuotas de poder interno en el partido. Entre los más destacados estaban Ricardo Balbín y Arturo Frondizi. El primero logró su cargo de diputado por la provincia de Buenos Aires y fue elegido por sus correligionarios como presidente del bloque radical; el segundo representó al radicalismo por la Capital Federal y secundó la labor de Balbín en la Cámara Baja. ${ }^{22}$ Las dificultades que tuvieron quienes defendieron su pertenencia a una corriente renovadora e intransigente del radicalismo para consolidar sus iniciativas y conductas políticas en el seno de la estructura partidaria, se contrarrestaron con la labor de oposición que ejercieron como primera minoría desde el Congreso. Para los radicales de esa tendencia, el trabajo de oposición en el Congreso que se inició en 1946 significó algo más que un ejercicio de oposición a las iniciativas de la mayoría peronista: les otorgó la posibilidad para afianzarse como orientadores ideológicos y responsables de la conducción del partido.

La confrontación entre peronistas y radicales en el Congreso se libró al amparo de las disposiciones constitucionales vigentes y expresó, en mayor o menor grado, los rasgos presidencialistas propios del sistema político argentino. En ese sentido, los conflictos entre gobierno y oposición fueron de orden político-institucional, pero no se manifestaron de la misma manera a lo largo de los gobiernos consecutivos de Perón. ${ }^{23}$ Hasta mediados de 1948, y en líneas generales, hubo libertad de expresión para el trabajo parlamentario y el debate marcó la esencia de la discrepancia entre gobierno y oposición. El derecho de la mayoría que puso en ejercicio el peronismo en los primeros dos años de

21 Ver, Tcach (1991).

22 Sobre la trayectoria política de Frondizi, Babini (1984). También, Rouquié (1975) y Szusterman (1998).

23 Para un análisis más amplio sobre el conflicto entre radicales y peronismo en el Congreso Nacional, García Sebastiani (2001: 27-66). 
gobierno no pareció ser distinto al de otros periodos democráticos previos. Hasta entonces, la oposición radical desplegó una serie de iniciativas parlamentarias que contribuyeron a delinear las líneas programáticas del Movimiento de Intransigencia y Renovación. Este grupo, finalmente, logró perfilarse como dominante en las estructuras nacionales de definición política del radicalismo a mediados de $1948 .{ }^{24}$ Las propuestas de los diputados radicales contemplaron una amplia variedad de temas, pero sobresalieron aquellos que hicieron referencia al papel que debía asumir el Estado en la organización económica y social del país. Los problemas planteados sobre la cuestión formaban parte del clima de ideas de la época, y tanto radicales como peronistas estuvieron comprometidos en propuestas afines y no diametralmente opuestas. La escasa distancia ideológica de las agrupaciones políticas más votadas se constituiría como uno de los rasgos más peculiares de los partidos que acabarían conformando, tras la experiencia, el sistema bipartidista en la vida política argentina.

Los proyectos presentados por los representantes radicales en el Congreso Nacional ponen en entredicho la pertenencia exclusiva al peronismo de iniciativas encaminadas a mejorar la situación social de amplios sectores de la sociedad argentina y a potenciar al Estado como garante del desarrollo socio-económico. Los diputados radicales fomentaron, por ejemplo, la libertad de asociación gremial, el derecho de huelga y la participación de los trabajadores en los beneficios de la industria. ${ }^{25}$ Las propuestas radicales contemplaron, también, la extensión de las funciones asistenciales del Estado. Por ejemplo, entre los proyectos legislativos del radicalismo tuvieron cabida la creación de colonias de vacaciones infantiles gratuitas; la protección y asistencia a huérfanos, niños y adolescentes; la redacción de un código para el niño; la extensión de los servicios sociales y el fomento de un seguro de vida colectivo para todos los trabajadores; vacaciones anuales y licencias con sueldo a empleados y obreros; jubilaciones e indemnización para los accidentes de trabajo; la distribución gratuita de libros escolares; la extensión de la educación primaria a los adultos analfabetos, y el apoyo a la construcción de viviendas económicas. ${ }^{26}$ Tampoco fueron exclusivas del peronismo las propuestas de nacionalización del los servicios y bienes públicos; es más, las discusiones sobre cómo llevar e cabo las nacionalizaciones no eran nuevas y estaban en el debate político

24 Ver al respecto Boletín de la Unión Cívica Radical, 1 (14 de agosto 1948) y Del Mazo (1957: 142-154).

25 Diario de Sesiones de la Cámara de Diputados ( DSCD) (1946: X, 486-489).

26 DSCD (1946: IV, 610-612; V: 309, 314 y 317-318; VI: 275-276; XI: 599-600 y $780-$ 781), $D S C D$ (1947: I, 484-488) у DSCD (1948: I, 109-123, 216-217 у 367-370). 
argentino desde los años treinta. Los diputados radicales presentaron proyectos para nacionalizar la explotación petrolera, los ferrocarriles, los tranvías, los teléfonos, el gas, la electricidad y los frigoríficos, ${ }^{27}$ pero además presionaron para que el gobierno se comprometiera en un diálogo parlamentario para las decisiones de política económica. ${ }^{28}$

Peronistas y radicales también estuvieron de acuerdo en incorporar nuevos ciudadanos a la vida política. Desde el comienzo de las sesiones parlamentarias de 1946, unos y otros fundamentaron la necesidad de ampliar el carácter representativo de las elecciones mediante la concesión del voto a la mujer y la conversión de los territorios nacionales en provincias. ${ }^{29}$ Diputados del partido en el gobierno y de la oposición pretendieron convertir en leyes proyectos que hacían referencia al diseño institucional del país y que tendrían implicaciones en la distribución del poder político y, en definitiva, en el sistema de partidos. Lo cierto es que unos y otros procuraron transformar en futuros votos los argumentos esgrimidos en el recinto parlamentario. La oposición logró, sin embargo, que la ley de sufragio femenino fuese aprobada en una sesión determinada y no en la que los peronistas pretendían. En ese sentido, significó un relativo logro de aquélla en términos de control parlamentario sobre el ejecutivo peronista. El desplazamiento sistemático del debate sobre la provincialización de los territorios nacionales de El Chaco y La Pampa desde los inicios de las sesiones parlamentarias de 1946, y su aprobación definitiva en 1951, se correspondió con las intenciones gubernamentales de conseguir votos de los nuevos ciudadanos a favor de su partido para las elecciones que se celebrarían en 1952. ${ }^{30}$

Con todo, el conflicto entre gobierno y oposición en el Congreso adquirió nuevos perfiles desde mediados de 1948. La aparentemente resuelta reorganización de la UCR bajo la conducción de los sectores intransigentes había permitido al partido mantener las mismas cuotas de representación institucional en el Congreso tras las elecciones de marzo de 1948. Sin embargo, el nuevo ordenamiento constitucional alteró las reglas de la dinámica parlamentaria entre la mayoría peronista y la oposición radical a partir de 1949. Por enton-

$27 \operatorname{DSCD}(1946:$ I, 94, 123 у 684).

28 Fundamentalmente, DSCD (1946: I, 563-568, 743-744 y 666-698; III, 135, 345-346; IV, 630-632; V, 38-40, 62-69, 105-111 у 610-735; X, 671-673), DSCD (1947: I, 193-194 у 287-327; II, 229, 311 y 451; III, 324), DSCD (1948: I, 154, 468-469; Tomo II, 1.1171.118; III, 1.793).

DSCD (1946: I, 98-99, 105-107), DSCD (1947: I, 77, 73-98 y 435-436; III, 203-258).

30 DSCD (1946: I, 112), DSCD (1951: II, 1.140-1.201). La ley 1.532 había sido promulgada en 1884 para organizar los territorios nacionales. Entre sus disposiciones, destacaba el artículo por el cual cualquier territorio podía pasar a ser provincia si tenía más de 60.000 habitantes según Censos Nacionales. 
ces, ciertas reformas introducidas en la Constitución acentuaron las características presidencialistas del sistema político. La división de poderes se mantuvo vigente conforme a los preceptos constitucionales de 1853, pero se ampliaron las facultades del ejecutivo. La más importante fue la posibilidad de que el presidente pudiese ser reelecto; otras disposiciones ampliaron su injerencia en los asuntos parlamentarios. ${ }^{31}$

Desde entonces, para la UCR, el Congreso dejó el espacio idóneo para postular sus iniciativas y fundamentar la disidencia o el acuerdo en materia programática contra el gobierno. En el periodo parlamentario abierto con la reforma constitucional, el Congreso se decantó progresivamente en un receptor de los proyectos del ejecutivo; los mecanismos de control parlamentario por parte de la mayoría fueron más rígidos y se acentuaron ciertas tendencias verticalistas (Ciria 1986b: 127-129; Waldman 1981: 63-64 y Luna 1986: I, 312). La Cámara de Diputados había dejado de ser el foro de debate político nacional para convertirse en el ámbito en el que la oposición desplegaría denuncias sobre los abusos que consideraban propios de las nuevas atribuciones constitucionales del ejecutivo. ${ }^{32}$ Desde el inicio de las sesiones en 1946, en el debate parlamentario se fueron sucediendo no pocas protestas por parte de la oposición radical sobre los procedimientos que alteraban ciertas reglas para el funcionamiento democrático y las posibilidades para la competencia política. ${ }^{33}$ A partir de 1949, sin embargo, las denuncias se extendieron en pro-

31 Por medio de la facultad de veto parcial, el presidente podía rechazar cualquier proyecto de ley y enviar a las Cámaras sólo lo impugnado para que se reconsiderase. También se amplió de 10 a 20 días hábiles el plazo de tiempo por el cual el ejecutivo podía hacer uso de veto presidencial. Se introdujo una nueva figura institucional: "el estado de prevención y alarma". El ejecutivo podía, así, prescindir del Congreso para establecer el estado de sitio. Se alteró la duración de los mandatos de los legisladores: diputados y senadores ocuparían sus cargos por seis años, renovándose por mitades cada trienio, de esa manera coincidían los mandatos de unos y otros. Otras reformas alteraron la vinculación de los ministros con el Congreso y el presidente. Las gestiones ministeriales pasaron a informarse al presidente antes que a las cámaras, desvinculando la relación institucional que tenían los ministros con ellas y reduciendo la capacidad de control parlamentario sobre el ejecutivo. Serrafero (1992: 85-115) y Slodky (1988: cap. III).

32 Los representantes radicales expresaron su desacuerdo con la nueva Constitución mediante la renuncia a las bancas de aquellos diputados que les correspondían renovar en 1950 de acuerdo a la normativa establecida cuando fueron electos en 1946. A partir de 1950, se quedaron, por iniciativa propia, con 21 diputados menos.

33 Los diputados radicales, por ejemplo, pidieron informes al gobierno sobre los ataques a los diarios de la oposición que se sucedieron a lo largo de 1947 y sobre la actuación de la Policía Federal en esos acontecimientos. También, denunciaron algunas violaciones de la libertad de expresión, de reunión y de imprenta y los condicionantes que tenía la 
cura de preservar al Parlamento como órgano de control institucional de la oposición al ejecutivo peronista. Los radicales se lanzaron a una campaña de descrédito hacia el gobierno y cuestionaron el aprovechamiento que el partido peronista hacía de unas funciones que eran propias del Estado y que, en definitiva, entorpecía a la libertad de expresión de los contrarios. Pidieron, por ejemplo, que se designase una comisión de investigación sobre la situación patrimonial de los diputados peronistas y, en general, de los altos cargos del partido que ocupaban funciones en el gobierno. También solicitaron informes acerca del suministro de fondos para las organizaciones políticas, sobre el origen de las fincas donde se instalaban los comités, centros o unidades básicas del partido peronista, o sobre la utilización de materiales y de personal de los servicios públicos para actividades propias de la agrupación política. Tampoco faltaron propuestas de la oposición para que se prohibiesen el uso de distintivos políticos a los empleados y funcionarios del Estado durante las horas de servicio y la colocación de símbolos partidistas en las mismas salas de sesiones, y otros edificios públicos. ${ }^{34}$

El conflicto político más álgido entre el gobierno y su oposición durante los últimos años del primer gobierno de Perón, fue, sin embargo, de orden institucional y se consumó mediante la suspensión, expulsión o desafuero de los diputados radicales del Congreso Nacional por acusaciones de agravio a personalidades del gobierno. Los enaltecidos discursos en torno al problema dieron cuenta de dos versiones diferentes acerca de la constitucionalidad del ejercicio político; una de la mayoría peronista y otra de la minoría radical. ${ }^{35}$ Para la primera, las medidas adoptadas en la Cámara contra algunos diputados del radicalismo -Ernesto Sanmartino, Agustín Rodríguez Araya, Ricardo Balbín, Atilio Cattáneo y Mauricio Yadarola- se justificaron en una lectura particular de la Constitución. Para los segundos, por el contrario, la defensa de los valores constitucionales definió el carácter de la oposición en el Congreso a lo largo de todo el periodo considerado, y las represalias contra los diputados de la minoría sirvieron como fundamento, de cara a sus partidarios y simpatizantes, de que el peronismo no respetaba a sus adversarios políticos.

oposición radical para participar en emisoras de radio que, progresivamente, pasaron a pertenecer a personalidades vinculadas con el gobierno peronista. Ver, por ejemplo, DSCD (1946: IX, 833-834); DSCD (1947: I, 141; II: 312-314, 892-904; III, 128-130, 568-569 y 765; IV, 58) y DSCD (1948: IV, 3.212). 


\section{Los radicales de la provincia de Buenos Aires}

El progresivo desgaste del Congreso Nacional como espacio de enfrentamiento entre el peronismo y sus contrarios implicó también el comienzo de una coyuntura adversa para el ejercicio de la oposición. En su esfuerzo por atraer al conjunto de la sociedad civil a la causa peronista, una vez sancionada la nueva Constitución, el gobierno puso en práctica una serie de mecanismos de corte autoritario que acabaron limitando los ámbitos de expresión de quienes se manifestaban en su contra. ${ }^{36}$ Procurando no restarles condiciones como legales competidores políticos, el peronismo empleó todos sus esfuerzos para restar posibilidades a los partidos de la oposición de ser una alternativa política. Se inició, entonces, una campaña oficial de intimidación y de franco ataque a sus adversarios que derivó en una labor consecuente y progresiva de clausura de gran parte de los medios de comunicación no identificados abiertamente con las políticas peronistas. ${ }^{37}$ Con todo, los radicales tenían más compromisos que cualquier otro partido, ya que el electorado había depositado en ellos la responsabilidad de ser la principal fuerza de oposición en el orden nacional. El radicalismo, debía, por tanto, definir sus opciones de acuerdo al desarrollo del proceso político.

En medio de una situación desventajosa, el diseño de las prácticas políticas para oponerse al peronismo suponía contemplar otras acciones además de las desarrolladas en el Congreso. Lo cierto es que la unificación de todas las fuerzas que pugnaban en el interior de la UCR facilitaría la toma de decisiones. Como se ha señalado, desde febrero de 1948 los intransigentes habían logrado el control del Comité Nacional, que era máximo órgano de dirección y decisión del partido. Sin embargo, las diferencias entre radicales adquirió nuevos perfiles y no se trataron sólo de discrepancias entre unionistas e intransigentes. La pugna intrapartidaria se tradujo en la disputa de determinados dirigentes de las regiones claves en términos electorales por dotar de un estilo propio de conducción al partido. El enfrentamiento se libró por el dominio de las estructuras organizativas de la UCR y fueron las representaciones de las provincias de Córdoba y de Buenos Aires las protagonistas más destacadas en la compe-

36 Sobre el progresivo autoritarismo del gobierno peronista, Waldman (1981: 227 y ss.) y Little (1973: 645-662).

37 Para ello se había formalizado desde el Parlamento la Comisión Visca-Decker, para legitimar el cierre de los periódicos adversos. Según The Economist, 27 de mayo de 1950, esa comisión había clausurado más de 150 periódicos hacia finales de abril de 1950. Cf. Plotkin (1993: 126). Sobre el control gubernamental sobre los medios de comunicación masiva, ver, Sirvén (1984), Sánchez Zinny (1958: I) y Confalonieri (1956: 181-195). 
tencia. En medio de ambas, los sectores que entrada la década del 40 se denominaron unionistas por propiciar alianzas electorales con otros partidos del espectro partidista, que habían reunificado sus fuerzas a partir de 1950 alrededor de Unidad Radical, y que controlaban fundamentalmente el Comité de la Capital Federal, buscaban algún espacio para desplegar acciones y no quedarse al margen de la lucha intra partidaria. ${ }^{38}$

En 1952 se realizarían nuevas elecciones generales y en ellas Perón se presentaría como candidato para renovar su cargo otros seis años. De cara a la contienda electoral y por todos los medios que le quedaban a su alcance, la UCR tenía que convencer al electorado de que representaba una opción política diferente y que podía forjarse como partido de referencia para el antiperonismo. No todas las corrientes de la intransigencia estaban representadas en el Comité Nacional; quienes lo controlaban eran los intransigentes cordobeses, liderados por Amadeo Sabattini. Especialmente interesados por conservar dicho dominio ante el creciente prestigio que estaban logrando en la política nacional otros dirigentes de la intransigencia, como era el caso de Balbín, aquellos no supieron cómo conjugar una política de oposición que pudiese aglutinar al antiperonismo. Fueron, en cambio, los sectores intransigentes del radicalismo de la provincia de Buenos Aires los que se esforzaron, entre 1949 y 1951, para convertirse en los referentes políticos más creíbles contra el peronismo. Mediante la revalorización de los principios doctrinales y la reactivación de sus potencialidades políticas procuraron sacar el mejor beneficio del trabajo partidario para hacer de él la opción política de oposición al gobierno peronista. $^{39}$

La intransigencia bonaerense no estuvo exenta de diferencias internas que estaban relacionadas, más bien, con ideas distintas por parte de sus principales líderes, Balbín y Moisés Lebensohn, sobre cuál debía ser el sentido político de un partido arraigado en la historia nacional. El primero, con una visión más pragmática de la política y apoyada por un poder de oratoria locuaz, se movió en aquellos espacios de confrontación política que le permitieron convertirse en el líder de la oposición con más opciones para disputar el cargo de presidente a Perón. Esencialmente, desarrolló su actividad política en el Congreso Nacional como diputado por la provincia de Buenos Aires y presidente del bloque opositor. Teniendo tan legítimo y reconocido ámbito para la acción política, relegó a un segundo plano su labor como presidente del comité de la UCR bonaerense, cargo que había logrado en los comicios internos celebrados

38 Para la reunificación de los unionistas, Tcach (1991: 147-153).

39 Para más detalle, García Sebastiani (2005: cap. 4). 
a fines de $1947 .{ }^{40} \mathrm{~A}$ finales de 1949 , fue acusado de desacato al gobierno y se le suspendieron los fueros como parlamentario a raíz de unas declaraciones públicas en la ciudad de Rosario (Monteverde 1981: 8-29). Los hechos realzaron su condición de líder de la oposición e incidieron entre las oportunidades políticas que la intransigencia bonaerense intentó aprovechar para conseguir el control de los órganos de decisión del partido en el ámbito nacional. Para liderar al partido necesitaba lograr la presidencia del Comité Nacional de la UCR. Era un puesto clave porque perfilaría las candidaturas del radicalismo para las próximas elecciones presidenciales. En la disputa estaban dos líderes intransigentes: Balbín y Santiago Del Castillo, este último alineado al sabattinismo. Finalmente, en febrero de 1950, Del Castillo fue elegido presidente del Comité Nacional con el apoyo de los sectores unionistas. ${ }^{41}$ Las tensiones entre la intransigencia bonaerense y la cordobesa se habían resuelto a favor de la segunda pactando, paradójicamente, con el sector que parecía ser el más acérrimo enemigo interno del partido. La elección anticipó una nueva correlación de alianzas en el seno del radicalismo. Apenas un mes después, en marzo de 1950, Balbín tuvo otro revés político: fue derrotado en las elecciones para gobernador de la provincia de Buenos Aires por los candidatos peronistas. ${ }^{42}$ Fue, sin embargo, su encarcelamiento una vez acabados los comicios bonaerenses el que le dotó de un valor simbólico que sus correligionarios intransigentes de la provincia supieron aprovechar para configurar una imagen del radicalismo como defensor de las libertades públicas en su lucha política contra el peronismo. La defensa que emprendieron los intransigentes bonaerenses a favor de la libertad de Balbín se convirtió en el elemento catalizador de la estrategia del radicalismo en una coyuntura signada por la convocatoria de una futura confrontación electoral y con ciertas limitaciones para la actividad opositora. Que Balbín lograse conformar la opción más creíble del antiperonismo se debió, en gran medida, a las actividades que desarrolló Lebensohn como presidente del Comité de la UCR de la provincia de Buenos Aires.

Lebensohn fue uno de los dirigentes que más se esforzó por dejar constancia de que pretendía dotar al radicalismo de una organización que garantizara

40 Sobre las elecciones internas del radicalismo bonaerense, Provincias Unidas, 48, 19 de agosto de 1947. Sobre la reorganización del comité bonaerense, Del Mazo (1957: 76-92).

41 Para el desarrollo de la reunión partidaria, El Día, 6 y 9 de febrero de 1950.

42 La fórmula peronista encabezada por Domingo Mercante había obtenido 486.549 votos y la de la UCR 283.454. Según las autoridades del Comité de la UCR de la provincia de Buenos Aires, los resultados habían sido alentadores, ya que habían significado un repunte para el radicalismo cercano al $32 \%$ respecto a la confrontación electoral previa celebrada en la provincia para sustituir a parte de los representantes en el Congreso Nacional. Boletín de la Unión Cívica Radical, 12, 8 de julio de 1950: 6. 
la vinculación de las políticas concluyentes del partido con las preocupaciones del afiliado común. ${ }^{43}$ Por eso, ayudó a que se organizaran las bases del partido, y especialmente la juventud. Desde diciembre de 1949 fue presidente del Comité de la UCR bonaerense y, como tal, potenció la actividad política del partido en la provincia. Supo comprometer a la militancia radical en una campaña de movilización ciudadana y de proselitismo político destinada a proyectarse en la política nacional y a dar resonancia del caso Balbín entre las restantes fuerzas de oposición y entre la opinión pública. Por ejemplo, estableció la Jornada por la libertad de Balbín para recaudar fondos y organizar visitas a la cárcel de Olmos y actos públicos a favor de su liberación. Paralelamente, fomentó la afiliación de nuevos miembros al radicalismo, aceleró la formación de secretarías y subcomités para el asesoramiento político, técnico y jurídico de los representantes del partido, y dispuso la creación de un fondo permanente de propaganda y de una imprenta para la difusión de las actividades radicales en la provincia. ${ }^{44}$

El creciente protagonismo logrado por los intransigentes de la provincia de Buenos Aires como los referentes más válidos de oposición frente al peronismo no fue del agrado de los sectores de la intransigencia sabattinista, que aún mantenían el control de las estructuras nacionales del partido. En noviembre de 1950, Balbín había sido condenado a cinco años de prisión, lo que congelaba sus posibilidades de lograr la candidatura de la UCR para las próximas elecciones presidenciales. La situación no podía ser más propicia para reacomodar la alineación de las tendencias internas del partido; estaba en juego el liderazgo nacional del radicalismo. Por entonces, se celebró la Convención Nacional de la UCR y las discusiones pusieron de manifiesto las diferencias de la intransigencia en el ámbito nacional. Los sabattinistas defendieron la abstención electoral como la estrategia de oposición al peronismo que el renovado radicalismo unionista terminó apoyando (Tcach 1991: 147-148). Defender la abstención suponía dos cosas. Primero, no utilizar los escasos espacios de expresión que tenía la oposición para conectar con la opinión pública. Segundo, coartar las posibilidades de crecimiento en el interior del partido de líderes radicales alternativos al sabattinismo. Con su líder encarcelado y desestimando las propuestas de abstención de sus correligionarios cordobeses, los intransigentes de la provincia de Buenos Aires estaban en un difícil momento de definición política. El indulto que el gobierno decidió conceder a Balbín

43 Sobre la labor de Lebensohn, Lebensohn (1956), Pasalaqua (1980: 4-7) y Gómez (1993).

44 Sobre la labor de Lebensohn al frente del Comité de la UCR de la provincia de Buenos Aires, Boletín de la Unión Cívica Radical, 12, 8 de julio de 1950: 6. 
con el inicio del año 1951 reavivó las posibilidades del radicalismo de la provincia de Buenos Aires para competir internamente contra la propuesta abstencionista de Sabattini y luchar por la candidatura de aquél para las próximas elecciones presidenciales. Sin embargo, las ya desfavorables condiciones para el desarrollo de la oposición empeoraron a comienzos de 1951.

El peronismo quiso asegurarse la reelección de su líder, por lo que desplegó todos los mecanismos institucionales que tuvo a su alcance para restar condiciones de competencia política a los partidos de la oposición. Un conflicto sindical iniciado a finales de 1950 en el gremio ferroviario, pero que dos meses más tarde se había extendido a otras organizaciones laborales, derivó en una sucesión de detenciones a trabajadores, dirigentes sindicales y políticos involucrados, pronosticando un endurecimiento en las relaciones entre gobierno y oposición. ${ }^{45}$ Inmediatamente después se produjo el cierre de La Prensa. Este periódico de alcance nacional era irreductiblemente opositor a Perón pero, al igual que La Nación, había logrado sobrevivir a la cooptación gubernamental de las empresas periodísticas. ${ }^{46}$ Las posibilidades para la expresión contraria al gobierno peronista habían empeorado. Sin embargo, unas nuevas disposiciones electorales y el adelanto de los comicios de renovación presidencial para noviembre de 1951, supusieron un definitivo golpe para los partidos en la oposición. La principal novedad de la nueva ley electoral fue la sustitución del sistema de lista incompleta -instaurado por la ley Sáenz Peña- por el de circunscripciones y la prohibición de formar coaliciones electorales. Dichas reformas afectaban especialmente al radicalismo porque, con el propósito de reducir al mínimo la representación institucional de la oposición, el gobierno hizo una partición convenientemente ajustada a su favor de las circunscripciones en que se dividían los distritos electorales. ${ }^{47}$

Los intransigentes de la provincia de Buenos Aires tuvieron que acomodarse a las reglas del juego político que marcaba la coyuntura sin renunciar a sus mermadas posibilidades de acción como competidores políticos leales. Las elecciones de 1951 pondrían a prueba las posibilidades de la UCR de aglutinar al antiperonismo. Mientras que las restantes tendencias internas del partido especulaban sobre la abstención electoral como la mejor forma para oponerse al peronismo, la intransigencia bonaerense apostó por proyectar su campaña de proselitismo político como la propia del radicalismo en la lucha

45 Para las derivaciones del conflicto ferroviario en las relaciones del gobierno y la oposición política, Little (1979: 331-372), Doyon (1977: 437-473) y Luna (1986: II, 52-60). Para el conflicto con La Prensa, Luna (1986: II, 13-31) y Sirven (1984: 94-115).

47 Sobre las implicaciones de la distribución de la geografía electoral en la alternancia política, Taylor / Gudgin / Johnston (1986: 183-192). 
antiperonista de cara a los comicios. Para ello, prosiguió con las líneas de acción política que venía desarrollando desde 1949, pero y como parte de un plan orgánico de propaganda preelectoral, fomentó simultáneamente tres frentes: la celebración de asambleas públicas, la difusión de la prensa partidaria y la organización de congresos sectoriales.

A lo largo de 1951 y con el fin de promocionar a Balbín como el mejor candidato de la oposición para las elecciones, los radicales bonaerenses organizaron una serie de actos públicos por las localidades de la provincia para el "esclarecimiento de la verdad argentina", en los que participaron los principales dirigentes, diputados nacionales y provinciales de la intransigencia. ${ }^{48} \mathrm{El}$ semanario Adelante, editado en La Plata y en el que se comprometió el grupo de la intransigencia fiel a Balbín, logró burlar con bastante éxito la persecución gubernamental a la prensa contraria y se constituyó en un espacio tanto de difusión doctrinal del partido como de denuncias contra la libertad de expresión de la oposición. ${ }^{49}$ Finalmente, los congresos sectoriales celebrados por el radicalismo bonaerense entre 1950 y 1951 y organizados en torno a la problemática agraria, de la juventud, de los trabajadores y de las mujeres, pusieron de manifiesto la preocupación del partido por políticas aperturistas hacia nuevos sectores, antimonopolistas y de gestión corporativa en materia económica. ${ }^{50}$ Las propuestas del radicalismo desplegadas en el Congreso Nacional habían demostrado que la oposición también quería propiciar el mejoramiento de las condiciones de vida de determinados sectores y que para ello había pensado en avanzados programas en materia económica y social. Los debates de las reuniones sectoriales propiciadas por los intransigentes de la provincia de Buenos Aires confirmaron que no sólo el peronismo tenía un proyecto de país sobre bases progresistas para esa época. En ese sentido, las elaboraciones ideológicas y programáticas del radicalismo moderno que cobraron cuerpo a la luz de la acción opositora durante el primer gobierno peronista constituyen uno de los puntos de partida para fundamentar las características más sobresalientes del sistema bipartidista argentino. Las diferencias entre peronismo y radicalismo, una vez más, no hay que buscarlas en aquellos elementos que pudieran marcar una distancia ideológica entre los dos grandes

48 “... el presidente del Bloque parlamentario Nacional de la UCR, Ricardo Balbín, ha iniciado su lucha en la calle para hacer conocer las verdades que el gobierno no permite que se haga por la prensa o por la radio", Adelante, 24 de febrero de 1951. Sobre la campaña de "esclarecimiento de la verdad argentina"; Adelante, 24 de marzo de 1951 y 5 de abril de 1951. También, UCR, Informe del comité de la Provincia de Buenos Aires (1951: 1-2).

49 Ver, por ejemplo, Adelante, 24 de febrero de 1951 y 4 de abril de 1951.

50 UCR. Comité de la provincia de Buenos Aires (1950), (1951 a) (1951 b) y (1951 c). 
partidos del país. El estilo político que cada uno hizo suyo para conquistar al electorado ayuda más a desvelar la preferencia recurrente u ocasional de los votantes argentinos por uno y otro de los grandes partidos nacionales.

Con todo, a los intransigentes de la provincia de Buenos Aires les quedaba una importante carta por jugar en el interior del partido para certificar el liderazgo político del antiperonismo en el ámbito nacional. La UCR tenía pendiente resolver las candidaturas de presidente y vicepresidente para las elecciones de 1951. La Convención radical, celebrada a comienzos de agosto de 1951, proclamó la fórmula Balbín-Frondizi pero certificó la ruptura de las fuerzas intransigentes. ${ }^{51}$ Las candidaturas se aprobaron con la ausencia de los delegados de la provincia de Córdoba. Éstos, con el control real de las estructuras del partido y el apoyo implícito de los unionistas para sus posturas de abstención, no lograron hacer frente al consenso logrado por los radicales bonaerenses como los portadores de la más clara alternativa política de oposición frente al peronismo.

\section{Socialistas y antiperonistas}

El universo de antiperonistas que no tenían representación en las instituciones del Estado era muy amplio. En él tenían cabida diversas agrupaciones civiles, publicaciones periódicas o ciertas personalidades con ideas influyentes, cuyas críticas calaron de diversa manera entre la opinión pública. Algunas mantenían contactos con los partidos políticos, pero otras eran sólo organizaciones con una clara convicción antiperonista. El Partido Comunista, los trotskistas y PS completaban el frente opositor sin posibilidades de manifestarse por los canales institucionales. Los comunistas habían tenido una participación activa en la formación de la Unión Democrática, pero históricamente su injerencia en la vida política argentina había sido escasa y se había concentrado en el mundo sindical. El apoyo de los sectores trabajadores a Perón supuso para los comunistas la reformulación de sus postulados y el consentimiento de algunas políticas gubernamentales, por lo que sus acciones no implicaron al partido en destacados conflictos con el gobierno. ${ }^{52}$ El caso del PS era, sin embargo, diferente. Los resultados de las elecciones de 1946 le habían dejado sin representación en las instituciones del Estado por primera vez desde la implantación de los procedimientos de apertura democrática para formar gobiernos en la Argentina. Los votos al PS no fueron suficientes ni siquiera en la Capital

51 Sobre el desarrollo de la reunión de la UCR, El Día, 5-7 de agosto de 1951.

52 Para la evolución del Partido Comunista durante la década peronista, Real (1962). 
Federal o en la provincia de Buenos Aires, tradicionales ámbitos de apoyo electoral, para obtener representación en el Congreso Nacional o en la legislatura bonaerense. Además, durante toda la década peronista, el gobierno municipal de la ciudad de Buenos Aires prescindió de su Concejo Deliberante, habiendo sido éste un ámbito tradicionalmente influyente y de actuación política para el PS. ${ }^{53}$

Las elecciones de 1946 significaron, entonces, un verdadero descalabro para el partido y presagiaron el ocaso de una de las fuerzas políticas más importantes de la vida política argentina de la primera mitad del siglo Xx. La falta de representación en las instituciones políticas nacionales, provinciales o en los ámbitos municipales relegó al PS de los espacios más propicios y garantizados para el ejercicio de una política de oposición. Pero, además, ese inesperado revés político tuvo para los socialistas implicaciones aún más profundas que pusieron en cuestión las propias formas de actuación política y de mediación social del partido. La imposibilidad de actuación en el Congreso Nacional a favor de las demandas de gremios vinculados al partido difícilmente podría compensar las limitaciones en la promoción de los líderes sindicales socialistas para dirigir una organización liderada por profesionales de clases medias. Desde su cargo como Secretario de Trabajo y Previsión, Perón había entablado contactos con consolidados dirigentes sindicales afiliados al socialismo que serían claves para la configuración de sus bases de apoyo. ${ }^{54} \mathrm{Sin}$ embargo, la ausencia de los socialistas en el Parlamento no implicó una retirada del partido de la lucha política. La estrepitosa derrota se tradujo en desesperados esfuerzos de los dirigentes socialistas por lograr representación y mantenerse de algún modo en el debate político. El PS manifestó su oposición al peronismo a través de formas y canales de diferente rango y carácter que el radicalismo que sí había logrado representantes en las instituciones para el ejercicio de la competencia política.

Los socialistas nunca le perdonarían a Perón el hecho de haber logrado la movilización política de los trabajadores en la Argentina, siendo ése el principal objetivo del PS desde comienzos del siglo Xx. El peronismo había hecho suyas viejas reivindicaciones del partido a favor de los sectores trabajadores, provocando en los dirigentes socialistas un antagonismo acérrimo e irreconciliable hacia Perón y todo su entorno gubernamental. La oposición del PS fue consecuente en ataques, críticas y argumentos que contribuyeron a fraguar en

53 Al respecto, Walter (1993) y (1974: 173-197).

54 Era el caso, por ejemplo, de Ángel Borlenghi o Atilio Bramuglia, antiguos afiliados al PS que formaron parte del gabinete de Perón, como Ministro del Interior y de Relaciones Exteriores, respectivamente, Rein (1998: 51-83) y Torre (1990: 50-89). 
la opinión antiperonista más obstinada la idea de que el peronismo representaba la versión argentina de los movimientos totalitarios de la Europa de entreguerras. Dicha opinión conformó el punto de partida para cualquier justificación del antiperonismo que se desplegó a partir del derrocamiento de Perón en 1955.

Una vez convencidos de los resultados electorales de 1946 y en aras de recuperar credibilidad entre un electorado perdido y que se había decantado por Perón, los dirigentes socialistas se pronunciaron a favor de un recambio generacional en el interior del partido. Prometieron, como en otras ocasiones, "nuevos métodos (y la) colaboración fervorosa de un admirable contingente de jóvenes" 55 para potenciar la actividad partidaria, pero tales llamamientos no se correspondieron con una inmediata apertura de nuevos elencos para dirigir los destinos del partido que procuró conservar celosamente un reducido grupo de dirigentes históricos. En la búsqueda de alternativas a la falta de representación institucional para expresar su disidencia con el gobierno, los socialistas no innovaron demasiado. Más bien, concentraron sus esfuerzos en recursos políticos que gozaban de consenso histórico y que le habían proporcionado ventajas oportunas en la trayectoria política de la agrupación. Para dar a conocer sus valoraciones sobre los diferentes temas de actualidad y sus críticas al gobierno peronista, los socialistas desplegaron su oposición de acuerdo a conocidas prácticas proselitistas del partido, como la celebración de actos públicos y la difusión de la prensa partidaria, La Vanguardia.

La opinión del periódico socialista se consagró como la crítica más áspera que tuvo Perón desde que había asumido la presidencia. La Vanguardia había reaparecido como semanario en enero de 1945 cuando por décadas se había editado a diario. A pesar de que dicha circunstancia era un signo de la declinación del partido, su lectura no sólo estaba circunscrita al círculo de afiliados y allegados al partido, sino que gozaba de aceptación entre cierto grupo de profesionales, estudiantes y, en general, un público defensor de los principios democráticos y progresistas propios de la época. La crítica a Perón, su esposa y a destacados miembros del gobierno fue progresivamente más estridente en sus editoriales, comentarios, informaciones y caricaturas. El gobierno expresó sus molestias mediante diferentes intentos de clausurar la publicación socialista hasta que finalmente la Dirección General de la Policía de la ciudad de Buenos Aires decretó el cierre de la imprenta en agosto de 1947. ${ }^{56}$ Lógicamente, el

55 La Nación, 7 de mayo de 1946.

56 El gobierno consideró como "una impostura periodística" el hecho de que el periódico socialista criticara sobre los gastos ocasionados por Eva Perón en su viaje a Italia. $L a$ Prensa, 21 de agosto de 1947. 
cierre del semanario socialista exasperó los ánimos de los dirigentes del partido. ${ }^{57}$ El suceso marcó un momento clave en el diseño de ciertas prácticas partidarias destinadas a articular una disidencia al gobierno que lograse repercutir en las decisiones políticas del electorado. Desde entonces, el PS endureció sus argumentos de crítica al gobierno y se pronunció por acelerar algunos cambios en la organización interna del partido. Las restricciones a la libertad de la expresión opositora justificaban para los socialistas sus denuncias acerca de que los métodos del gobierno peronista eran los propios de los sistemas totalitarios. Tales denuncias terminaron conformando los argumentos de confrontación política del partido de cara a la contienda electoral de marzo de 1948 para renovar diputados y nombrar autoridades municipales. Achacaban al gobierno de haberse "convertido en una máquina de propaganda, destinada a endiosar a la pareja presidencial (para) preparar las elecciones de marzo ... Para ello... tendremos de nuevo promesas copiosas, aguinaldos dobles, pan dulce, sidra, juguetes, dinero distribuido a la marchanta...". 58

En esas elecciones, los votos a los socialistas aumentaron un $10 \%$ respecto a los de 1946 y permitieron que el partido obtuviese la representación de un diputado, Teodoro Bronzini, en la legislatura de la provincia de Buenos Aires. Aunque no alcanzaron para que el PS llevase diputados al Congreso Nacional, los resultados no fueron tan catastróficos como los de entonces. La comisión electoral del partido advirtió sobre la necesidad de aprovechar ese crecimiento de votos para futuras convocatorias y propuso, entonces, la conveniencia de nuevos métodos de propaganda política y de organización de las campañas electorales. La consigna era descentralizar unas funciones en la materia en que eran propias del Comité Ejecutivo Nacional del partido y poder llegar al electorado con prácticas más directas de propaganda política. ${ }^{59}$ Ciertamente, tales propósitos hacían necesario llevar a cabo algunos cambios en la organización y en el programa político del partido. El Congreso Nacional del PS celebrado a medidos de 1948 (se hacían cada dos años) sirvió de marco para un debate en el que las autoridades del partido se dirimían por serios planteamientos de supervivencia política. Si el PS quería proseguir en la contienda política y afirmarse en el panorama político nacional con un número de votantes aceptables, debía potenciar cambios en la organización, de los elencos dirigentes y de sus

57 En la "Declaración del Comité Ejecutivo Nacional" ante la clausura de los talleres de $\mathrm{La}$ Vanguardia, los socialistas denunciaron el suceso como "... un episodio definitivo del proceso encaminado a destruir los derechos democráticos fundamentales", pero además aprovecharon para atacar la política de favores económicos y sociales del gobierno peronista, La Prensa, 29 de agosto de 1947.

59 XXXVI Congreso Nacional del Partido Socialista (1948). 
programas. ${ }^{60} \mathrm{Se}$ ajustaron algunos aspectos de la Carta Orgánica del partido para agilizar su posición en la competencia política, evitar el sectarismo y modernizar la agrupación. Por ejemplo, se rebajó el número de afiliados necesarios para abrir centros socialistas; se amplió el número de miembros del Comité Ejecutivo Nacional del partido y se dispusieron normativas menos restringidas para su acceso; se rebajó la edad de afiliación y se levantaron restricciones (como el casamiento religioso, ser profesional en juegos de azar o batirse a duelo en cuestiones de honor) que dificultaban el contacto de la agrupación con la sociedad civil. ${ }^{61}$ Fuera de discusión quedó la actualización del programa del partido. A pesar de esas reformas, al PS le costaba desprenderse de los signos de identidad propios de la agrupación política y entendió que el esfuerzo por proseguir con la publicación de La Vanguardia, sopesando todos los obstáculos de la aventura clandestina, era el mejor camino para salvaguardar uno de los espacios de crítica que mantenía cierto prestigio y fidelidad entre la opinión pública antiperonista. Otras publicaciones partidarias como El Socialista, primero, y Nuevas Bases, más tarde, se sumaron a las iniciativas socialistas por mantener vivas y difundir sus ideas, principios y posturas programáticas.

En los desesperados intentos del partido por mantenerse de algún modo en la competencia política y conciliar opciones de oposición que repercutiesen en las preferencias políticas del electorado, el PS tomó decisiones atípicas a las asumidas históricamente por el partido. Prueba de ello fue, por ejemplo, la resolución del PS por votar en blanco para la elección de representantes para la Convención Constituyente, fundamentando su oposición a la reforma de la Constitución. La negativa de los dirigentes socialistas a participar en dichas elecciones había provocado públicos enfrentamientos en el interior del partido que el peronismo supo aprovechar para sumar adeptos. ${ }^{62}$ Sin embargo, las diferencias ahondaron en el seno de la dirigencia en la reunión general del partido celebrada en 1950. Las discrepancias entre los dirigentes socialistas no eran nuevas en la historia del partido; incluso algunas habían dado origen a escisiones y a otras organizaciones políticas. ${ }^{63}$ Sin embargo, las propuestas para el debate que algunos diri-

60 Según Bronzini, presidente de la reunión, "Nuestro problema más importante es sobre todo un problema de organización. Siempre fuimos el partido de las ideas. Hemos sido siempre el partido de los principios. Quizá esta sea la forma de que seamos el partido grande, dotado de capacidad para asimilar hombres nuevos que trabajen al lado de los viejos militantes", El Socialista, 12 de agosto de 1948.

61 El Socialista, 24 de agosto de 1948.

62 Los militantes disidentes con la decisión del partido llegaron a editar una publicación que denominaron "Unidad Socialista" que pareció tener apoyo gubernamental, El Socialista, 14 de diciembre de 1948.

63 Sobre las escisiones del PS, Dickmann (1949: 197-242) y Walter (1977: cap. 6 y 10). 
gentes socialistas llevaron a esa reunión pusieron de manifiesto de manera clara, y como no había ocurrido en el interior del partido desde la emergencia de Perón en la escena política, la necesidad de entender por qué un amplio sector de la ciudadanía argentina se había decantado por el peronismo. La discusión giró en torno al programa que el partido defendería en las elecciones generales que se convocarían inminentemente. El debate se centró en dos proyectos ideológicamente divergentes: por un lado, el de la minoría que defendió Julio González, uno de los miembros más jóvenes del CEN y distanciado de los veteranos conductores del partido como podían ser Nicolás Repetto o Enrique Dickmann; por otro, el de la mayoría que sostuvo Américo Ghioldi. Para González, la discusión significaba "tocar fondo" y acusó a la falta de autocrítica para encontrar las causas del fracaso político y de la incapacidad del partido para llegar a la clase obrera. Para evitar el anquilosamiento de la agrupación política, su tesis contenía un replanteamiento general de las tareas y, sobre todo, de un programa socialista que, elaborado en los momentos de fundación del partido, había perdido actualidad y ya no se distinguía como exclusivo del PS porque otros grupos políticos se habían adueñado de las ideas y realizado parte de sus propuestas. Las ideas de González no lograron imponerse. La mayoría de los dirigentes socialistas respaldaron la moción de Ghioldi para quien el partido estaba doctrinariamente bien orientado, pero la manifiesta disidencia pronosticó futuras e irreversibles discrepancias en el seno de la organización. ${ }^{64}$

\section{Consideraciones finales: la oposición a partir de las elecciones de $\mathbf{1 9 5 1}$}

Una nueva victoria de Perón era predecible, pero las elecciones que se adelantaron para noviembre de 1951 gozaban de una especial expectación política por dos cosas. Por un lado, porque mediría la diferencia en el ámbito nacional entre seguidores y contrarios a Perón; votar por los candidatos de la UCR se traducía básicamente en no votar por Perón. Por otro lado, el registro electoral se había más que duplicado respecto al de 1946 debido a la incorporación de las mujeres. La campaña se desarrolló con bastantes dificultades para la oposición. La utilización que hizo el peronismo del aparato gubernamental dejó poco margen para que los candidatos del radicalismo pudiesen difundir su propaganda electoral por un medio masivo como era la radio ${ }^{65}$ Balbín y Frondizi

64 Sobre las divergencias entre Ghioldi y González, Nuevas Bases, 15 de noviembre de 1950, González (1950) y Ghioldi (1950).

65 Desde mediados de 1947, la mayoría de las radiodifusoras no habían podido escapar al control de los medios de comunicación por parte del gobierno y pasaron a pertenecer a 
acudieron a los tradicionales mítines políticos en rocambolescas giras por todo el país para llegar a un electorado que no había que convencer demasiado si no quería votar por Perón. Como antes se ha dicho, no todo el radicalismo estuvo de acuerdo en que el partido se presentase a esas elecciones y con esos candidatos. La alternativa de intervenir en un movimiento militar para impedir que Perón fuese electo nuevamente presidente resultó atractiva para no pocos sectores del radicalismo, especialmente para intransigentes sabattinistas y para la renovada Unidad Radical. La participación de algunos dirigentes de esas tendencias en el levantamiento encabezado por el general Benjamín Menéndez, que irrumpió en medio de la campaña electoral, evidenció un claro cambio en la percepción de la oposición sobre las posibilidades para la competencia política ${ }^{66}$ El silencio de las autoridades de la UCR sobre el suceso otorgó credibilidad a la intención de desestimar el compromiso de lealtad a las reglas del juego político y a considerar opciones desleales para que los adversarios de Perón ampliasen los espacios para la acción política.

Los resultados de las elecciones de noviembre de 1951 afianzaron al peronismo en el poder y fueron el mejor parámetro de medición política entre aquél y sus adversarios políticos. Perón logró cerca del $62 \%$ de los votos y la UCR aproximadamente el $32 \%$; las restantes fuerzas políticas alcanzaron un $6 \%$. La concentración del voto contrario a Perón hacia el radicalismo confirmó al peronista y a la UCR como los grandes partidos en el ámbito nacional y prácticamente la desaparición en la escena política de los restantes partidos de la oposición, el Partido Demócrata Progresista, el Partido Demócrata (ex PDN), o el PS. En ese sentido, dichas elecciones certificaron, de alguna manera, el origen de la configuración del sistema bipartidista argentino que, a partir de entonces y cuando fue posible la competencia democrática, se basó en la disputa entre peronismo y radicalismo. Las nuevas normativas que reglamentaron el ejercicio electoral habían restringido las posibilidades de representación de la oposición. La UCR sólo había logrado 14 escaños en el Congreso Nacional, mientras que el partido peronista había conseguido 135 ; un 10 y $90 \%$ respectivamente del total.

La despareja distribución de los recursos institucionales con que se iniciaba el segundo gobierno de Perón dificultaba el ejercicio de la oposición. Las reglas para la competencia política que había logrado imponer el peronismo implicaron al gobierno y a la oposición en una redefinición de sus relaciones. Finalmente, aquellas terminaron incidiendo en las posibilidades de los antipe-

empresas vinculadas con hombres del gobierno. Sánchez Zinny (1958: I, 206-208), Confalonieri (1956: 190-191) y Sirvén (1984: 118). 
ronistas para estimar opciones disruptivas o desleales en aras de obtener una mayor participación política. Tanto el golpe fracasado de Menéndez en noviembre de 1951 como otra conspiración descubierta en febrero de 1952 encabezada por el coronel José F. Suárez, evidenciaron la presencia de actores y conflictos de diferente tipo en la oposición al peronismo. La complicidad de ciertos dirigentes socialistas y radicales con las rebeliones militares permitió ampliar el frente adversario hacia el gobierno, alentando la polarización de la vida política argentina entre peronistas y antiperonistas. Consolidado electoralmente, y con el ánimo de apaciguar las opciones desleales de la oposición, Perón especuló con la opción de crear un clima de diálogo con las fuerzas de oposición. El cambio de actitud gubernamental se puso a prueba en los contactos iniciados, a comienzos de 1952, con destacados dirigentes políticos del conservador Partido Demócrata y del PS, como lo eran Reynaldo Pastor y Enrique Dickmann. El acercamiento a Perón le costó, a uno, la presidencia de su partido y, al otro, la expulsión del selecto círculo de dirigentes socialistas, pero también permitió que varios opositores implicados meses antes en los levantamientos militares pudiesen retornar a la escena política. ${ }^{67}$ Las propuestas de Perón para dialogar con la oposición cuajaron a medias entre las filas del radicalismo. En junio de 1952, el Comité Nacional decidió confiar a su grupo parlamentario la tarea de entrevistarse con el ministro del Interior para reclamar la liberación de varios presos políticos implicados en el golpe militar y el levantamiento del "estado de guerra interno", decretado a raíz del mismo suceso (Tcach 1991: 198). Tales contactos no llegaron a efectivizarse y fue Crisólogo Larralde, interventor por entonces del comité de la Capital Federal, quien, con el pretexto de denunciar los obstáculos que se ponían para las tareas de elecciones internas del partido en ese distrito, se entrevistó con Ángel Borlenghi para pactar la liberación de algunos correligionarios presos (Luna 1986: III, 247).

La política de apertura ofrecida por el gobierno requería, sin embargo, dos cosas. Por un lado, un reconocimiento de la oposición como fuerza política alternativa al peronismo. Por otro, algún gesto de flexibilización gubernamental hacia sus contrarios. Sin embargo, la consolidación electoral del peronismo le permitió desplegar su poder en diferentes áreas de sensibilidad social que entorpecían cualquier tipo de compromiso o diálogo político con los partidos de la oposición. En la búsqueda de una base de apoyo lo más amplia posible, el Estado peronista se esforzó por politizar ciertos aspectos de la vida cotidiana y de la cultura popular que se extendieron a los ámbitos educativo, militar,

67 El acercamiento de Dickmann y Perón fue propiciado por Á. Borlenghi, Bejar (1979: 83-93). 
universitarios, de la administración pública, de los medios de comunicación, de la beneficencia, del deporte, de los homenajes, generando un intercambio simbólico entre Perón y sus seguidores que impregnaría de nuevos imaginarios políticos la cultura política argentina (Plotkin 1993: parte IV; Rein 1998: cap. III; Rein, M. 1998, Bernetti y Puiggrós 1983 y Ciria: 1986b). Como ejemplos, entre otros, la asistencia de servicios sociales y materiales por parte de la Fundación Eva Perón a los sectores trabajadores y, en general, al colectivo social con menos recursos; el adoctrinamiento político partidario en los libros de texto y en las actividades culturales y lúdicas de los estudiantes y de los jóvenes; y el control de las radiodifusoras por personalidades vinculadas al gobierno. Esos intentos de politización de la sociedad para lograr "una comunidad organizada" contribuyeron a exacerbar la polarización de la vida política de los argentinos detrás de una dinámica excluyente entre peronismo y antiperonismo. Lo cierto es que en medio de ese clima poco contemporizador para la participación de la oposición, ciertos antiperonistas procedentes del campo político e intelectual se involucraron en la construcción de planes conspirativos contra el gobierno para privarlo de legitimidad en la competencia política. El partido en el gobierno y su oposición, en definitiva, perseguían lo mismo: deslegitimar al otro para participar en el espacio público. El clima de desestabilización política se aceleró a partir de abril y mayo de 1953. Por entonces, las sedes partidarias de los socialistas, radicales y demócratas de la Capital Federal fueron asaltadas e incendiadas. El gobierno acusó a los partidos de la oposición de provocar tales incidentes y varios de sus dirigentes fueron encarcelados. Las relaciones entre gobierno y oposición estaban en uno de los momentos más álgidos de tensión política.

Radicales y socialistas ahondaban sus discrepancias internas en el seno de sus respectivas organizaciones partidistas. Los socialistas, reunidos en Mar del Plata en abril de 1953 para la infaltable cita del congreso partidario, se negaron a escuchar las explicaciones de Dickmann sobre su acercamiento al gobierno y decidieron expulsarlo. Apoyado por otros dirigentes como era el caso de Repetto, Ghioldi o Alicia Moreau de Justo, Dickmann pasó a la ofensiva. Fundó el Partido Socialista de la Revolución Nacional y pidió la intervención judicial al PS. El juez terció a favor del grupo de los disidentes, proclamó la caducidad de las autoridades del Comité Ejecutivo Nacional del PS y traspasó el control de la edición de La Vanguardia a un grupo del entorno de Dickmann, reconocido como única autoridad socialista. El alboroto político provocado por el acercamiento de Dickmann al gobierno peronista estaba latente en el seno de la agrupación socialista desde los inicios del peronismo. En la búsqueda de estrategias partidarias para recuperar electorado y espacios políticos arrebatados por los peronistas, las diferencias se habían manifestado entre los dirigentes socialistas desde 1946. Tampoco habían faltado expulsiones a socia- 
listas con cargos intermedios en el partido que se habían decantado por apoyar a Perón. ${ }^{68}$ El caso de Dickmann tenía implicaciones diferentes porque era un histórico dirigente socialista, con puestos claves en la dirección y en la representación institucional del partido desde hacía varias décadas. Además, su separación conllevó rupturas familiares entre algunos de los miembros del partido, relacionados por lazos matrimoniales y de sangre que nunca se recompusieron. Finalmente, él y su grupo terminaron aceptando lo que, cuatro años atrás, criticaba Julio González en el congreso partidario de 1950. Dickmann, sin dejar de recriminar su expulsión del partido, fundamentó su postura de colaboración con el gobierno peronista porque "la dirección del partido se embarcó en una intransigencia aburrida, en una oposición suicida, en una lucha estéril..." ${ }^{69}$ Meses más tarde, una revocación parcial de la sentencia judicial reconoció a dos fuerzas como representantes del PS: los tradicionales que se agregaron la rúbrica de "Casa del Pueblo" y los de Dickmann que terminaron llamándose "PS de la Revolución Nacional"..$^{70}$ Estos últimos, presentaron candidatos propios en las elecciones de abril de 1954 para renovar parte de los diputados y senadores, pero fracasaron rotundamente tanto en la Capital Federal como en la provincia de Buenos Aires. Muchos de ellos terminaron empleándose en organismos oficiales, lo que les facilitó el empeño de retomar con la edición de La Vanguardia hasta la definitiva caída de Perón.

Los radicales, tras las elecciones de 1951, mantuvieron una representación de sólo catorce diputados en el Congreso Nacional, de los cuales siete pertenecían al sector unionista y los otros siete al de los intransigentes. Las diferencias entre ambas corrientes de la UCR eran públicas y notorias. Las decisiones que pudiera tomar el partido en el recinto parlamentario dependían, en última instancia, de quien ejerciera la presidencia del bloque. Por entonces, el intransigente Oscar Alende, representante por la provincia de Buenos Aires, desempeñaba esa labor, por lo que los diputados no alineados a esa tendencia se mantuvieron bastante al margen de las resoluciones partidarias en un marco con escasas posibilidades para la confrontación política. Las elecciones inter-

68 Era el caso, por ejemplo, de Alfredo López, a quien se le acusó de iniciar conversaciones con el gobierno al margen de las disposiciones partidarias; Carlos María Bravo de la comisión de administración del centro socialista de Vicente López (provincia de Buenos Aires); y de José Oriente Cavalieri, quien expresó sus objeciones a la política partidaria a través de El Socialista, que era el periódico, por entonces, oficial del PS debido a la clausura de La Vanguardia. El Comité Ejecutivo Nacional del partido se había reunido especialmente a finales de 1948 para decretar la expulsión de esos cuadros intermedios. El Socialista, 14 de diciembre de 1948.

70 Sobre las divisiones del PS, Verde Tello (1963). 
nas celebradas entre los meses de mayo y junio de 1952 no variaron sustancialmente la correlación de fuerzas en la organización, excepto en la Capital Federal donde, ajustada pero finalmente, habían logrado ganar los intransigentes. Dichas elecciones certificaron el liderazgo del Movimiento de Intransigencia y Renovación en el ámbito nacional, pero reabrieron la lucha política entre las diferentes fuerzas políticas de esa tendencia del radicalismo. Los intransigentes de la provincia de Buenos Aires habían estrechado vínculos con los propios de esa corriente en la Capital Federal, liderados por Frondizi, en el enfrentamiento interno con las fuerzas sabattinistas. Estas últimas procuraron preservar el control del Comité Nacional mediante una política de apertura hacia los representantes de los territorios nacionales para que apoyasen su gestión de la conducción partidaria. Sin embargo, la incorporación de los nuevos representantes del partido terminó teniendo el efecto contrario. En la Convención Nacional de 1953 se renovaron las discrepancias en la organización partidaria. La solución de abstención electoral para los próximos comicios que propiciaron los intransigentes cordobeses y los sectores unionistas no la compartieron la mayoría de los delegados intransigentes alineados detrás de las propuestas defendidas en la reunión por el bonaerense Moisés Lebensohn. La repentina muerte de este último en el mes de junio aceleró la correlación de poder interno en el frente interno contra Sabattini y sus allegados. Y fue Frondizi, y no Balbín a pesar de la imagen que se había procurado construir de él como líder político de los antiperonistas, quien consiguió obtener consenso entre la mayoría de las fuerzas intransigentes del partido; incluso las del interior. En septiembre de 1953, un acuerdo entre dirigentes intransigentes de la provincia de Buenos Aires, Capital Federal y del litoral hizo posible que Frondizi se convirtiera en el candidato del Movimiento de Intransigencia y Renovación para presidir el radicalismo y que finalmente fuese elegido presidente del Comité Nacional en enero de 1954 en una sesión impugnada por unionistas y sabattinistas. ${ }^{71}$

El estado de competencia interna en que se encontraba el principal partido de la oposición ofrecía poco margen para nombrar un interlocutor del radicalismo ante cualquier estrategia de conciliación que esperaban auspiciase el gobierno. Algunos líderes del radicalismo estaban ausentes de la escena política porque habían decidido exiliarse por temor a nuevos acosos gubernamentales tras su participación, en 1951, a favor de los huelguistas ferroviarios o del golpe de Menéndez. En diciembre de 1953, de cara a la inminente convocatoria electoral para renovar parte de la Cámara del Congreso y el cargo de vicepresidente del país, se sancionó una ley de amnistía que, al menos, aliviaría el

71 Tcach (1991: 209-222). 
estado de tensión política. Sin embargo, otras nuevas reglamentaciones electorales, que afectaban a la proporcionalidad del escrutinio, acabaron restringiendo, aún más, las posibilidades de representación de la oposición. El nuevo marco normativo en materia electoral restaba opciones a la postura abstencionista de sabattinistas y unionistas para consagrarse como la más idónea de defender en el interior del partido y obligaba al radicalismo a definir propuestas y candidatos ante una situación condicionante: los partidos políticos que no se presentaran a las elecciones perderían personería jurídica.

La designación de Frondizi al frente del máximo órgano partidario de la UCR conllevaba, por tanto, lidiar frontalmente con los opositores internos para sobrevivir políticamente a la coyuntura. Mandó intervenir a varios distritos contrarios a las nuevas autoridades partidarias, pero otros eran especialmente conflictivos, como era, por ejemplo, el de la Capital Federal. Si bien en él la correlación de fuerzas se había definido interna y democráticamente hacia los intransigentes, los unionistas conservaban aún cuotas de poder nada despreciables. Frondizi logró zanjar las diferencias mediante la confección de una lista electoral en la que distribuyó equitativamente las catorce candidaturas en disputa. Para conciliar las diferencias con el radicalismo del interior, Frondizi apoyó la candidatura de Crisólogo Larralde para el cargo de vicepresidente del país, bastante consensuada entre los representantes de la Convención del partido. Los resultados no habían empeorado para el radicalismo respecto a los obtenidos en las elecciones del 1951. En el total nacional, las fuerzas opositoras habían alcanzado el 36\% de los votos y el oficialismo, cerca del 63\%; la diferencia había sido menos despareja en la Capital Federal. Por ese distrito, los peronistas habían obtenido 844.000 votos y los radicales 645.000 , pero a pesar de los buenos resultados de los segundos, la nueva disposición electoral sólo permitió la entrada de un diputado de la oposición por la Capital Federal. ${ }^{72}$

La disputa en el seno del radicalismo entre frondicistas y sus allegados, por un lado, y sabattinistas y unionistas, por el otro, favoreció que estos últimos maniobrasen opciones desleales y conspirativas al margen de las decisiones partidarias. Tradicionales dirigentes unionistas como Mauricio Yadarola o Miguel Ángel Zavala Ortiz habían vuelto a la escena política en 1954; el primero, con conocidos contactos con los sectores militares, había logrado ser electo diputado nacional por la provincia de Córdoba. Fueron ellos los más

72 Según las nuevas normativas electorales, los distritos de Capital Federal, Córdoba, Entre Ríos y Buenos Aires debían elegir a todos los representantes por circunscripciones, menos a uno. La banca de este último se le adjudicaba al candidato del distrito que hubiera reunido más votos sin necesidad de haber sido electo en su respectiva circunscripción. En esos distritos, por tanto, la representación de la minoría quedaba reducida. 
visibles interlocutores de un tardío acercamiento del radicalismo a un confluente diálogo conspirador en el que estaban inmersas la Iglesia y la corporación militar desde mediados de $1954 .{ }^{73} \mathrm{El}$ pasaje, por tanto, de opciones leales y desleales por parte del principal partido de la oposición estuvo vinculado con las pugnas de poder en el interior del radicalismo. El control que aparentemente Frondizi parecía tener sobre las estructuras organizativas y de decisión partidistas no terminó conciliando a las distintas fuerzas de la UCR. Cuando a mediados de 1955 el antagonismo entre peronismo y antiperonismo se encontraba en una lógica irreconciliable, y de la que participaban otros actores y no sólo los partidos políticos, Frondizi acató el juego de la conciliación política ofrecido por Perón y habló por la radio como representante de la oposición pidiendo garantías para la democratización de la vida política, la pacificación interna y el levantamiento del "estado de guerra interno" decretado desde finales de 1951. Desde hacía nueve años, ningún político de la oposición había podido hacer uso de la radio como medio de difusión de sus posturas, por lo que el discurso de Frondizi tuvo amplia repercusión entre la opinión pública. Aunque desde las elecciones de 1951 la identidad de la UCR había quedado definida como partido aglutinante del voto contrario al peronismo, el camino final de oposición a Perón escapó del control del elenco dirigente de la agrupación política. Fueron los radicales que propiciaron las posturas abstencionistas quienes asintieron el derrumbe institucional del peronismo que dirigieron los militares y la Iglesia. Las diferencias entre las diversas tendencias del radicalismo sobre cómo enmarcarse en la recta final contra Perón terminarían profundizando posturas irreconciliables que dividirían al partido luego de la caída del peronismo.

\section{Bibliografía y fuentes citadas}

Adelante (La Plata).

Anuario del Partido Socialista (1946). Buenos Aires.

Anuario del Partido Socialista (1948). Buenos Aires.

Babini, Nicolás (1984): Frondizi: de la oposición al gobierno. Buenos Aires: Celtia. Bejar, María Dolores (1979): “La entrevista Dickmann-Perón”. En: Todo es Historia, 143, pp. 83-93.

Bernetti, Jorge/Puiggrós, Adriana (1993): Peronismo, cultura política y educación (1945-1955). Buenos Aires: Galerna.

73 Para el detalle de este proceso, fundamentalmente, Caimari (1995: cap. IV) y Ruiz Moreno (1994). También, Potash (1986: cap. VI). 
Bianchi, Susana (2001): Catolicismo y peronismo. Religión y Política en la Argentina 1943-1955. Tandil: Instituto de Estudios Histórico-Sociales-Prometeo.

Boletín de la Unión Cívica Radical (1948).

Boletín de la Unión Cívica Radical (1950).

Caimari, Lila (1995): Perón y la Iglesia Católica. Religión, Estado y sociedad en la Argentina (1943-1955). Buenos Aires: Ariel.

Cantón, Darío (1973): Elecciones y partidos politicos en la Argentina. Historia, interpretación y balance. Buenos Aires: Siglo XXI.

Cataruzza, Alejandro (1997): Los nombres del poder: Alvear. Buenos Aires: Fondo de Cultura Económica.

Ciria, Alberto (1986a): Partidos y poder en la Argentina moderna (1930-1946). Buenos Aires: Hispamérica.

- (1986b): Política y cultura popular: la Argentina peronista 1946-1955. Buenos Aires: Ediciones de la Flor.

Confalonieri, Orestes (1956): Perón contra Perón. Buenos Aires: Editorial Antigua.

Dahl, Robert (1966): Political Oppositions in Western Democracies. New Haven and London: Yale University Press.

- (1973): Regimes and Oppositions. New Haven and London: Yale University Press.

- (1974): La poliarquía, Participación y oposición. Madrid: Guadiana.

De Privitellio, Luciano (1994): "Sociedad urbana y actores políticos en Buenos Aires: el 'partido' independiente en 1931". En: Boletín de Historia Argentina y Americana Dr. Emilio Ravignani, 9, 3, pp. 75-96.

Del Mazo, Gabriel (1957): El radicalismo. El Movimiento de Intransigencia y Renovación (1945-1957). Buenos Aires: Ed. Gure.

Diario de Sesiones de la Cámara de Diputados (DSCD) (1948-51).

Dickmann, Enrique (1949): Recuerdos de un militante socialista. Buenos Aires: Editorial La Vanguardia.

Doyon, Louise (1977): “Conflictos obreros durante el régimen peronista”. En: Desarrollo Económico. Revista de Ciencias Sociales, pp. 437-473.

El Día (Buenos Aires).

El Partido Socialista y la Unión Democrática (s/f): Resoluciones y documentos. Buenos Aires.

El Socialista (Buenos Aires).

Entrevista a Eduardo Colom: Archivo de Historia Oral, Instituto Torcuato Di Tella.

Entrevista a Oscar Albrieu: Archivo de Historia Oral, Instituto Torcuato Di Tella.

Fennell, L. C. (1971): "Congress in the Argente Political System: An Appraisal”. En: Agor, W. H. (ed.), Latin American Legislatures: Their Role and Influence. Analices for the Countries. New York: Praeger Publishers.

Fitte, R./Sánchez Zinny, E. (1944): Génesis de un sentimiento democrático. Buenos Aires.

Fraga, Rosendo (1993): El General Justo. Buenos Aires: Emecé.

García Sebastiani, Marcela (2001): "Peronismo y oposición política en el Parlamento argentino. La dimensión del conflicto con la Unión Cívica Radical (1946-1951)”. En: Revista de Indias, 221, pp. 27-66. 
- (2003): "The Other Side of Peronist Argentina: Radicals and Socialists in the Political Opposition to Perón (1946-1955)”. En: Journal of Latin American Studies, 35, pp. 311-339.

- (2005): Los antiperonistas en la Argentina peronista. Radicales y socialistas en la politica argentina entre 1943 y 1951. Buenos Aires: Prometeo.

Ghioldi, Américo (1950): Los trabajadores, el señor Perón y el Partido Socialista, ¿Perón es socialista o retrógado? Discurso pronunciado en el $37^{\circ}$ congreso del PS. Buenos Aires.

Gómez, Alejandro (1993): La significación de Lebensohn en el radicalismo. Buenos Aires: CEAL.

González Esteves, Luis (1980): "Las elecciones de 1946 en la provincia de Córdoba". En: Mora y Araujo, Manuel/Llorente, Ignacio (comps.), El voto peronista. Ensayos de sociología electoral argentina. Buenos Aires: Editorial Sudamericana, pp. 318364.

González, Julio (1950): La oportunidad del Partido Socialista. Reflexiones sobre su acción futura. Buenos Aires: Editorial La Vanguardia.

Halperin Donghi, Tulio (1962): Historia de la Universidad de Buenos Aires. Buenos Aires: Editorial Universitaria de Buenos Aires.

- (1986): Argentina. La democracia de masas. Buenos Aires: Paidós.

Horowitz, Joel (1990): Argentine Unions, The State \& the Rise of Perón, 1930-1945. Berkeley: University of California.

Horvath, Laszlo (ed.) (1993): A Half Century of Peronism, 1943-1993: An International Bibliography. Stanford: Stanford University.

Ionescu, Ghita/De Madariaga, Isabel (1977): La oposición. Pasado y presente de una oposición política. Madrid: Espasa Calpe.

James, Daniel (1990): Resistencia e integración. El peronismo y la clase trabajadora argentina 1946-1976. Buenos Aires: Editorial Sudamericana.

Kolinsky, Eva (ed.) (1987): Opposition in Western Europe. London: Croom Helm.

La Nación (Buenos Aires).

La Prensa (Buenos Aires)

Larra, Raúl (1942): Lisandro de la Torre. Vida y drama del solitario de Pinas. Buenos Aires: Editorial Claridad.

La Vanguardia (Buenos Aires).

Lebensohn, Moisés (1956): Pensamiento y acción. Buenos Aires.

Linz, Juan (1973): “An Authoritarian Regimes: The Case of Spain”. En: Dahl, Robert, Regimes and Oppositions. New Haven and London: Yale University Press, pp. 171-259.

- (1997): "Democracia presidencial o parlamentaria ¿Qué diferencia implica? En: Linz, Juan y Valenzuela, Arturo: La crisis del presidencialismo. 1. Perspectivas comparativas. Madrid: Alianza Editorial, pp. 25-143.

Little, Walter (1973): "Party and State in Peronist Argentina, 1945-1955". En: Hispanic America Historial Review , 53, 4 , pp. 645-662.

- (1979): "La organización obrera y el Estado peronista, 1943-1955”, Desarrollo Económico, 75, pp. 331-372. 
Luna, Félix (1971): El 45. Crónica de un año decisivo. Buenos Aires: Editorial Sudamericana.

- (1986): Perón y su tiempo, 3 tomos. Buenos Aires: Editorial Sudamericana.

Llorente, Ignacio (1980): “Alianzas políticas en el surgimiento del peronismo: el caso de la provincia de Buenos Aires”. En: Mora y Araujo, Manuel/Llorente, Ignacio (comps.): El voto peronista. Ensayos de sociología electoral argentina. Buenos Aires: Editorial Sudamericana, pp. 269-317.

Mackinnon, María Moira (1995): "Sobre los orígenes del Partido Peronista. Notas introductorias”. En: Ansaldi, Waldo/Pucciareli, Alfredo/Villarruel, José: Representaciones inconclusas. Las clases, los actores y los discursos de la memoria, 19121946. Buenos Aires: Editorial Biblos, pp. 223-156.

Macor, Darío/Tcach, César (eds.) (2003): La invención del peronismo en el interior del país. Santa Fe: Universidad Nacional del Litoral.

Mainwaring, S./Shugart, M. (1997): Presidencialism and Democracy in Latin America. New York: Cambrige University Press.

- (1994): "Juan Linz: Presidencialismo y democracia. Una revisión crítica”. En: Desarrollo Económico, 135, pp. 397-418.

Molinelli, Guillermo (1991): Presidentes y Congresos en Argentina: Mitos y realidades Buenos Aires: GEL.

Monteverde, Mario (1981): “Balbín preso”. En: Todo es Historia, 74, pp. 8-29.

Mustapic, Ana María (2000): “Oficialistas y diputados: las relaciones ejecutivo-legislativo en la Argentina”, en: Desarrollo Económico, 39, 156, pp. 571-595.

Mustapic, Ana María/Goretti, Mario (1992): “Gobierno y oposición en el Congreso: la práctica de la cohabitación durante la presidencia de Alfonsín”. En: Desarrollo Económico, 126, pp. 251-269.

Neiburg, Federico (1998): Los intelectuales y la invención del peronismo. Buenos Aires: Alianza Editorial.

Nudelman, Santiago (1947): El radicalismo al servicio de la libertad. Buenos Aires: Ed. Jus.

Panebianco, Angelo (1990): Organización y poder de los partidos políticos. Madrid: Alianza Editorial.

Pasalaqua, Eduardo (1980): “Moisés Lebensohn: apuntes históricos”. En: Entrelíneas, 8, pp. 4-7.

Pasquino, Gianfranco (1974): “L'opposizione difficile”, Rivista italiana de Scienza Politica, IV, 2, pp. 421-439.

- (1998): La oposición en las democracias contemporáneas Buenos Aires: Editorial Universitaria de Buenos Aires.

Plotkin, Mariano (1991): "Perón y el peronismo: un ensayo bibliográfico". En: Estudios Interdisciplinarios de América Latina y el Caribe, 2, 1, pp. 113-135.

- (1993): Mañana es San Perón. Propaganda, rituales políticos y educación en el régimen peronista (1946-1955). Buenos Aires: Ariel.

Potash, Robert (1986): El ejército y la politica en la Argentina, II, 1945-1962. De Perón a Frondizi. Buenos Aires: Editorial Sudamericana.

Provincias Unidas (Buenos Aires). 
Real, Juan José (1962): Treinta años de historia argentina, acción política y experiencia histórica. Buenos Aires: Ed. Anteo.

Rein, Mónica (1998): Politics and Education in Argentina, 1946-1962. New York: Armonk.

Rein, Raanan (1998): Peronismo, populismo y política. Argentina 1943-1955. Buenos Aires: Editorial Belgrano.

Repetto, Nicolás (1957): Mi paso por la política. De Uriburu a Perón. Buenos Aires: Santiago Rueda Editor.

Rouquié, Alain (1975): Radicales y desarrollistas. Buenos Aires: Shapire Ed..

- (1981): Poder militar y sociedad política en la Argentina I-hasta 1943. Buenos Aires: Emecé.

Ruiz Moreno, Isidoro (1994): La Revolución del 55. Buenos Aires: Emecé.

Sánchez Zinny, E. (1958): El culto de la infamia. Historia documentada de la Segunda Tiranía argentina. Buenos Aires.

Serrafero, Mario (1992): El presidencialismo en el sistema político argentino. Tesis de doctorado, I. U. Ortega y Gasset-Universidad Complutense de Madrid.

Shugart, M./Carey, J. (1992): President and Assamblies: Constitucional Design and Electoral Dynamics. New York: Cambridge University Press.

Siegler, Pedro (1984): Lisandro de la Torre y los problemas de su época. Buenos Aires: CEAL.

Sirvén, Pablo (1984): Perón y los medios de comunicación (1943-1955). Buenos Aires: CEAL.

Slodky, Javier (1988): El Estado justicialista. Buenos Aires: CEAL.

Smulovitz, Catalina (1988): Oposición y gobierno: los años de Frondizi. Buenos Aires: CEAL.

Szusterman, Celia (1998): Frondizi, la política del desconcierto. Buenos Aires: Emecé. Taylor, Peter/Gudgin, Graham/Johnston, R. (1986): "The Geogaphy of Representation: A Review of Recent Findings", en: Grofman, B./Lijphart A.: Electoral Laws and Their Consequences. New York: Agathon Press, pp. 183-192.

Tcach, César (1991): Sabattinismo y peronismo. Partidos políticos en Córdoba, $1943-$ 1955. Buenos Aires: Editorial Sudamericana.

Torre, Juan Carlos (1990): La vieja guardia sindical y Perón: sobre los orígenes del peronismo. Buenos Aires: Editorial Sudamericana.

- (dir.) (2002): Los años peronistas (1943-1955). Buenos Aires: Nueva Historia Argentina, 8, Editorial Sudamericana.

Tussie, D./Fedeman, A. (1972): “El golpe de Menéndez”. En: Todo es Historia, 67, pp. $10-23$.

UCR (1951): Informe del comité de la Provincia de Buenos Aires.

UCR. Comité de la provincia de Buenos Aires (1950): I Congreso Agrario "Tierra y libertad. Tandil.

UCR. Comité de la provincia de Buenos Aires (1951 a): II Congreso Agrario "Tierra y Libertad". Bahía Blanca.

UCR. Comité de la provincia de Buenos Aires (1951 b): I Congreso Gremial. Avellaneda. UCR. Comité de la provincia de Buenos Aires (1951 c): I Congreso Femenino. Lanús. 
Verde Tello, Pedro (1963): La división socialista. Su origen y desarrollo. Actual organización del Partido Socialista Democrático. Buenos Aires: Ediciones Libertad. Waldman, Peter (1981): El peronismo 1943-1955. Buenos Aires: Hyspamérica.

Walter, Richard ( 1977): The Socialist Party of Argentine, 1890-1930. Texas: Texas University Pres.

- (1968): Student Politics in Argentina. The University Reform and its Effects, 19181964. New York: Basic Books.

- (1974): "Municipal Politics and Government in Buenos Aires, 1918-1930". En: Journal of Interamerican Studies and World Affairs, XVI, 2, 74, pp. 173-197.

- (1993): Politics and Urban Growth in Buenos Aires, 1911-1942. Cambridge: Cambridge University Press.

XXXVI Congreso Nacional del Partido Socialista: 28 ordinario y 9 extraordinario (1948). Buenos Aires, 1948.

Zanatta, Loris (1999): Perón y el mito de la Nación católica. Iglesia y Ejército en los orígenes del peronismo 1943-1946. Buenos Aires: Editorial Sudamericana. 